\title{
Importance of the enteric nervous system in the control of the migrating motility complex
}

\author{
KW Romański \\ Department of Animal Physiology, Faculty of Veterinary Medicine, Wrocław University of \\ Environmental and Life Sciences, Wrocław, Poland
}

Received: April 28, 2016

Accepted: March 30, 2017

\begin{abstract}
The migrating motility complex (MMC), a cyclical phenomenon, represents rudimentary motility pattern in the gastrointestinal tract. The MMC is observed mostly in the stomach and gut of man and numerous animal species. It contains three or four phases, while its phase III is the most characteristic. The mechanisms controlling the pattern are unclear in part, although the neural control of the MMC seems crucial. The main goal of this article was to discuss the importance of intrinsic innervation of the gastrointestinal tract in MMC initiation, migration, and cessation to emphasize that various MMC-controlling mechanisms act through the enteric nervous system. Two main neural regions, central and peripheral, are able to initiate the MMC. However, central regulation of the MMC may require cooperation with the enteric nervous system. When central mechanisms are not active, the MMC can be initiated peripherally in any region of the small bowel. The enteric nervous system affects the MMC in response to the luminal stimuli which can contribute to the initiation and cessation of the cycle, and it may evoke irregular phasic contractions within the pattern. The hormonal regulators released from the endocrine cells may exert a modulatory effect upon the MMC mostly through the enteric nervous system. Their central action could also be considered. It can be concluded that the enteric nervous system is involved in the great majority of the MMC-controlling mechanisms.
\end{abstract}

Keywords: migrating motor complex, man, animals, intrinsic control, enteric nervous system

The so-called "motor complex" is the composed cyclic phenomenon traveling along the gastrointestinal tract and propelling the contents. Consequently, it is named the "migrating complex" $(43,313)$. The name "migrating electric complex" (262) or "migrating myoelectric complex" (42) was proposed when it was recorded utilizing the myoelectrical technique. When the mechanical recording method was applied, the name "migrating motor complex" was used $(63,141)$. A more uniform name, the "migrating motor complex" (MMC), as proposed by Weisbrodt (302) and used by others (96), applied regardless of the recording system, is also actual. When the MMC was referred to man, dog, or some other species in which the cycle is disrupted after a meal, the word "interdigestive" was added to the name of the cycle $(35,58)$. Although the term "interdigestive migrating complex" could be disputable, it is currently in use in monogastrics $(265,300)$. In rats, short MMC cycles, observed in the fasting state, can be substantially prolonged in the upper small intestine after feeding (29). In fasted guinea pigs, the duration of the MMC is similar to that in man or dog, but after feeding, it is prolonged (85). In ruminants, especially in sheep, the MMC also occurs in the postfeeding period. Therefore, in the ruminant species, in which no interdigestive period is present, the term

\footnotetext{
Corresponding address: Department of Animal Physiology, Faculty of Veterinary Medicine, Wrocław University of Environmental and Life Sciences

Norwida 31, Wrocław 50-375, Poland

Phone: +48 71 3205422; Fax: +48 71 3211567; E-mail: krzysztof.romanski@up.wroc.pl
} 
"interdigestive MMC" might be misleading (31). It is noteworthy that in sheep, the MMC cycles disappear in response to overfeeding. In pigs, as in ruminants, the same name of the pattern can be used, despite the MMC is more closely related to feeding (218). The MMC occurs principally in the stomach and small bowel and it is one of the basic motility patterns important for characterizing the gastrointestinal motility $(106,213)$. The cycle also arrives in the colon and it is independent of its presence in the small bowel $(152,224)$.

\section{Basic Characteristics of the MMC}

Once arrived, the MMC can persist in an undisturbed form returning regularly, cycle by cycle, even for $24 \mathrm{~h}$ and longer. However, its organization is not strictly uniform. As it has been stated by several authors $(28,251,325)$, the MMC cycle duration in man, dog, and sheep ranges within 90-120 min. However, in these species, some authors described more variable MMC duration periods like 100-150 min (227), 90-180 min (163), 85-110 min (117, 152), or 60-110 min (302). In man, according to Woodtli and Owyang (318), typical MMC cycles lasted for $80 \pm 27 \mathrm{~min}$ and atypical ones for $115 \pm 35 \mathrm{~min}$. In rats, duration of the MMC in the stomach was $16 \pm 5$ min whereas in the duodenum and jejunum, the values were $13 \pm 6$ and $16 \pm 6 \mathrm{~min}$, respectively $(6,9)$. In another report, the duration of the MMC cycles was $11 \pm 6 \mathrm{~min}$ in the antrum of the fed rats and $11 \pm 8 \mathrm{~min}$ in the duodenum (82). In fasted rats, the MMC cycle frequency can be even higher in the upper than in the lower small bowel since several complexes recorded in the jejunum never reach the ileum (29). Duration of the MMC in fasted sheep lasts usually for about $1 \mathrm{~h}$ or less (215). In sheep, undergoing the standard feeding regimen, duration of the MMC cycle was reported to be either $1 \mathrm{~h}(212)$ or $70-90$ min long $(29,215)$. When feeding with hay was supplemented with the addition of the concentrate, these values averaged from 90 to $144 \mathrm{~min}$ (29). Thus, the variability in the duration of the MMC can be substantial.

Within the MMC cycle, four phases are discernible (42). As proposed by Code and Marlett (42), the MMC phases are numbered consecutively due to the gradually enhanced gastrointestinal motor activity. Accordingly, during phase I, no or almost no contractions and spike bursts are present. In the course of phase II, the contractions and spike bursts become more intense reaching the apogeum during phase III of the cycle. Phase IV is observed in the most cases and its irregular character resembles phase II of the MMC. Similar to the complete MMC pattern, duration of its phases is also variable although phase variability is not greater than that of the cycle. In man, the reported average duration of gastric phases I-IV of the "typical" MMCs was 28, 42, 2.0, and $7.1 \mathrm{~min}$, respectively, whereas in the "atypical" cycles, it was $31,80,3$, and $0.8 \mathrm{~min}$, respectively (318). In the human duodenum, the average durations of the phases I-III of the MMC were 38, 50, and 5 min, respectively (188). In the duodeno-jejunum of man, the average durations of phases I-III were 20, 123, and 6 min, respectively (255). In the human jejunum, the average durations of phases I-III were 28 , 59 , and $4 \mathrm{~min}$, respectively (13). In the canine proximal stomach, the average durations of phases I-III were 52, 34, and $24 \mathrm{~min}$, respectively, whereas in the distal stomach, the values equaled to 60,30 , and 19 min, respectively (89). In a broader canine study, mean durations of the gastric MMC phases I-IV were 53, 23, 18, and $6 \mathrm{~min}$, respectively, the durations of duodenal phases were about 38, 46, 8, and 7 min, respectively and in the jejunum, these phases lasted 48, 46, 5, and $2 \mathrm{~min}$, respectively (231). Another study in dog showed that the mean durations of duodenal phases I-IV were 69, 20, 9, and 2 min, respectively (227). In the canine jejunum, the duration periods were equal to 40,35 , and 8 
for phases I-III, respectively (28). In the same study, the durations of the ovine jejunal phases I-III were 42, 40, and 6 min, respectively. In this study, phase IV was rather absent. In fasted guinea pigs, the reported durations of phase I in the duodenum, jejunum, and ileum averaged 10,12, and $13 \mathrm{~min}$, respectively. The relevant values for phase II were about 70, 67, and 72 min and for phase III, 3, 4, and 4 min, respectively. In fed animals, duration of phase I in the duodenum, jejunum, and ileum was about 7, 11, and 9 min, respectively and the relevant values for phases II and III were 118, 161, and $123 \mathrm{~min}$ and 3, 5 , and $4 \mathrm{~min}$, respectively (85). No report demonstrating the complete absence of a given phase in the course of normal MMC cycle in man and animals is available. Regular phase organization of the MMC, despite individual and species differences, allows to perceive the importance of its neural control and suggests the presence of distinct controlling mechanisms for each phase of the cycle.

The propagation velocity of the MMC is most characteristic for a given cycle once it is determined for phase III. Sometimes, it is also measured for phase II. In man, the reported duodenal migration velocity of phase III was approximately $11 \mathrm{~cm} / \mathrm{min}(63), 20 \mathrm{~cm} / \mathrm{min}$ (129), $12 \mathrm{~cm} / \mathrm{min}$ (76), or $8 \mathrm{~cm} / \mathrm{min}$ (7). In the human duodeno-jejunum, the reported values of the migration velocity of phase III were $9.3 \mathrm{~cm} / \mathrm{min}(63)$ or about $6 \mathrm{~cm} / \mathrm{min}(141,255)$. In the upper jejunum, migration velocity of phase III was also $6 \mathrm{~cm} / \mathrm{min}$ (76). In the human jejunum, similar values were observed, i.e., $6 \mathrm{~cm} / \mathrm{min}$ (7), $7 \mathrm{~cm} / \mathrm{min}$ (63), or $5 \mathrm{~cm} / \mathrm{min}$ (136). In man, the ileal migration velocity of phase III was much slower and oscillated around $1 \mathrm{~cm} /$ min (136). In dog, propagation velocity of phase III of the MMC in the duodenum was about $5 \mathrm{~cm} / \mathrm{min}$ (260). In the canine duodeno-jejunum, it averaged about $4 \mathrm{~cm} / \mathrm{min}(29,262)$. In the proximal jejunum of this species, the values were about $4 \mathrm{~cm} / \mathrm{min}$ (29). Other reported values regarding propagation velocity of the jejunal phase III were equal to $2-3 \mathrm{~cm} / \mathrm{min}$ (260) or to about $6-7 \mathrm{~cm} / \mathrm{min}$ (235). In the canine ileum, migration velocity of phase III was below $2 \mathrm{~cm} /$ $\min (262)$. In the hog's jejunum, migration velocity of phase III was about $19 \mathrm{~cm} / \mathrm{min}$ (141). In sheep, the mean propagation velocity from the duodenum till the ileum was about $19 \mathrm{~cm} /$ min (29), whereas in the proximal jejunum this value was $26 \mathrm{~cm} / \mathrm{min}$ (141). In the duodenojejunum of rats, propagation velocity of the MMC was $2 \mathrm{~cm} / \mathrm{min}$ or slightly faster (6). When the normal MMC cycle is considered, migration of phase III and of the whole cycle occurs regardless of the site of pattern origin. The migration of phase III in the small bowel as well as the migration of the whole cycle over the long distance suggests the presence of many inducing units in the subsequent intestinal segments. The units are well coordinated functionally and linked probably with the enteric nervous system. The organized migration along the bowel of each normal MMC cycle, with remarkable regularity, must be steered by fine control mechanisms involving the enteric network of intramural neurons. The smooth muscles are regarded merely as the effector organ. The composed arrangement, recurrence, variability, and well-organized migration of the MMC appear to be compelling elements for its imprecise, but repeatable organization.

\section{Luminal Conditions and the MMC}

The phases II and III of the MMC are propulsive regardless of the animal species and feeding regimen. When the duodeno-jejunal flow of digesta was compared in dog and sheep, the postcibal flow of the chyme was greater in the dog, whereas the interprandial flow (10 h after feeding) or after saline administration was comparatively lower in this species (29). The transit time in sheep after saline administration was slower than in the dog (28). Furthermore, 
in sheep, the digesta flow is not constant that can further slower its average flow rate through the bowel $(97,112)$. In both animal species, it was the slowest in the jejunum during phase I and much more rapid during phases II and III of the MMC. When the two latter phases were compared, the transit time was faster during phase II than during phase III of the MMC in both the dog and sheep. However, in these animals, changes in bolus migration velocity during the MMC phases were similar (28). It was found in man that the relation of propagated to stationary contractions during phase III was $1: 1$ and during phase II it was about 5:1 (3). In man, migration velocity and related propulsion during phase III were slower than during phase II since the migration of phase III was not completely antegrade $(8,17)$. It is possible that the intensity of digesta flow is one of the factors regulating the arrival of the MMC cycle in both the stomach and small intestine. It seems unlikely that the mechanisms controlling the intestinal transit so precisely, are not related to the nervous system. The movement of the luminal contents, either in the digestive or in the interdigestive periods, activates several controlling mechanisms due to the contact of chyme with the intestinal mucosa that contains mostly numerous mechanoreceptors and chemoreceptors. The stimulation of these receptors regulates the motility and transits either in the fasting state or postprandially.

Cessation of the phase III is practically tantamount to the disruption of whole MMC pattern. Feeding seems to be the most natural disruptive factor, at least in man $(259,290)$, $\operatorname{dog}(42,58)$, and some other monogastrics. Only sufficient amount of food can disrupt the MMC (304). In the dog, if the size of a meal is too small or duration of fasting is not long, the intestinal digesta flow does not exceed the rate $20-30 \mathrm{ml} / \mathrm{h}$. Then, the MMC is not disrupted (217). When the meal is relatively small, it can even provoke phase III arrival when given during the late phase II, but when offered during phase I it can induce irregular contractions and the motor response is much weaker (165). The presence of fluid or gas in the gastrointestinal tract may also influence the MMC. In man, aspiration of fluid and gas from the upper gastrointestinal tract decreases the duration of phase II and increases the duration of phase I of the MMC. Moreover, the instillation of acaloric fluid or gas into the stomach may prolong the duration of phase II (254). Administration of isotonic saline abolished the MMC for shorter periods than a complete meal either in all or only in 6 of 10 volunteers $(242,309)$. In dogs, intraduodenal placement of isoosmotic saline did not abolish the MMC, but slightly prolonged its average duration from 111 till $118 \mathrm{~min}$ due to prolonged duration of phase II. In this study, low-caloric meal prolonged the MMC cycle till $174 \mathrm{~min}$, with slight shortening of phase I and substantial elongation of phase II (54). The duration of phase III was rather not altered. Therefore, shortening of phase I and elongation of phase II can be treated as the inhibitory tendency toward the MMC inhibition. These results clearly indicate that in normal conditions, physical factors in the lumen can affect the MMC.

Oral administration of food abolished the MMC for a longer period than enteral nutrition (205). Interestingly, when the effect of intragastric feeding was compared with the effect of intraduodenal feeding upon the recurrence time of phase III, the latter procedure exerted stronger effect (146). The more nutrients are present in food when the longer disruption of the MMC occurs. The caloric load can thus strongly affect the interdigestive pattern, especially in such species like man $(188,243)$ and $\operatorname{dog}(54,58,233)$. In ruminants, relatively low-caloric load of the typical diet, especially of the hay given alone, can retain the MMC during the digestive period $(29,97,153)$. However, in sheep, the MMC can be slightly prolonged after feeding, but the effect seems to be the short lasting and dependent on the nutrient content, i.e., on the caloric value of the fodder $(29,98)$. The final effect of the caloric content of food upon the MMC is related to the type of nutrients present in food. In dogs, 
duration of MMC inhibition by lipids is the longest when compared with peptides or glucose; whereas in man, the effects of glucose and fat are not much different $(233,242)$. When ThiryVella loop was perfused with glucose-containing solutions, disruption of the MMC was limited to the loop indicating the local influences as it was noticed in the dog (69). In man, the intraduodenal infusion of medium-chain and long-chain triglycerides exerted different effect on the MMC in the gut. When medium-chain triglycerides were infused, no MMC disruption was denoted. Following the infusion of the long-chain triglycerides, the opposite effect was observed (292). When the effects of very long-chain and long-chain triglycerides were compared after intraduodenal infusion in healthy volunteers, about $46 \%$ and $23 \%$ of the MMC cycles were inhibited, respectively (129). The infusion of arachis oil, mixed with bile and pancreatic juice, into the duodenum and ileum disrupted the MMC in dogs. When the arachis oil was infused alone, disruption of the MMC was observed only in the duodenum (70). Intraileal infusion of the oleic acid emulsion in dogs also prolonged the length of the MMC cycle, exerting general inhibitory effect upon the small intestinal motility (65). Therefore, the effectiveness of lipids in the inhibition of the MMC is mostly related to the type of lipid and its digestion in the gut. The digestion products can trigger the MMC-inhibitory mechanisms and affect the cycle. The duodenal distension inhibited phase III-like spike bursts and induced the antro-pyloro-duodenal motor activity in the fasted state $(67,80)$. Physiological changes in the intraluminal $\mathrm{pH}$ (acidification and alkalization) exerted stimulatory effect upon the $\operatorname{MMC}(121,155,162,318)$. Intrinsic innervation is involved in the MMC control both during the fasted and the fed state and cooperates with hormones $(16,106)$. The afferent neural fibers originating from the mucosa transmit the signals from the lumen to the intramural ganglia $(41,100)$. The effectiveness of relatively weak intraluminal signals in their influence upon the MMC implies that the nervous system plays the major mediatory role in this regulation. Clear inhibitory effects upon the MMC, evoked by intraileal lipid infusions, might be strengthened and/or mediated also by the local hormonal influences. It is thus likely that the luminal factors may contribute to both the initiation and cessation of the MMC as well as to the MMC phase duration and may also modulate the irregular phasic contractions within the pattern by means of the neurohormonal mechanisms.

\section{Peripheral Peptidergic Control of the MMC}

Several regulatory substances can induce the phase III of the MMC and new regulators, affecting the MMC, are discovered almost every decade (301). They comprise the gastrointestinal hormones and some other chemical factors, mostly neuromodulators $(60,213,303$, 305). They represent endogenous peptide and non-peptide regulators and various xenobiotics. These regulators act rather peripherally and their action may possibly involve extrinsic mechanisms when they can cross the blood-brain barrier. However, the peptide regulators can pass this barrier usually in low quantities (128). They can bind to the receptors, located on extrinsic afferents within the gastrointestinal tract, which provokes the efferent extrinsic response. Furthermore, after postprandial inhibition, the MMC appears to return spontaneously, i.e., when activity of the inhibitory mechanisms declines without the evident contribution of additional influencing factors (29). Hormonal involvement is suspected to be important in the inhibition of the MMC by nutrients $(15,91)$. These regulators can act in part as hormones, and in part as neuromodulators. It is uncertain whether the role of postprandially released hormones is the cause or consequence of the cessation of the MMC 
cycles. It is also unclear that the exact role of the enteric nervous system is in the hormonal actions regarding the MMC. There are also several reasons to suggest the occurrence of exclusive neural influences in the control of the MMC $(40,186)$. The autonomic nervous system is responsible for these effects and it is equipped with some specific mechanisms, engaging the neuropeptides as well.

\section{Motilin}

Motilin was found to induce the premature phase III of the MMC during fasting in such species like man and dog $(122,290,316)$. During the interdigestive period, plasma motilin concentration fluctuates in concert with phase III in the stomach of the species $(122,291)$. Motilin antibodies disrupted naturally occurring MMC in the proximal small bowel but not in the jejunum and ileum $(148,194)$. Motilin antagonists exerted a similar effect (176). Acid, alkali, and fat can induce motilin release, increasing its level in the blood, particularly in dogs $(20,45,149)$. Glucose and amino acids can decrease plasma motilin levels (37). Thus, the data suggest that motilin itself can probably initiate phase III of the MMC, acting as the gut hormone released from the duodenal mucosa, although it remains obscure whether or not the endocrine action is accompanied by the involvement of the nervous system. It is in the stomach where motilin appears to be the most important for evoking the MMC. It may initiate phase III there, probably in some cooperation with other chemical regulators $(131,265)$. It was found that the induction of phase III of the MMC in the human stomach, unlike in the small bowel, was motilin-dependent (127). Motilin receptors, present in the pyloric antrum, are mostly located on nerves $(170,263,319)$. Therefore, the neuronal action of motilininduced phase III in the stomach is very probable. Other data indicate that small intestinal contractions can induce motilin release thus increasing plasma motilin concentration to the level sufficient to induce phase III of the MMC (223). This view also confirms the existence of an endocrine pathway for motilin action, although it is not known whether the mechanisms are sufficient to trigger the MMC in normal conditions. The motilin-producing cells were found mostly in the duodeno-jejunum and they produce the major portion of endogenous motilin (197). Motilin may thus be able to induce phase III of the MMC in an endocrine pathway, acting directly on the smooth muscles since the motilin receptors are present there (267). However, the substantial portion of motilin receptors occurs also in nerves $(107,267)$. It is possible that the greater motilin receptor density, as present in the intestinal smooth muscle, unlike in nerves, may be required to induce the MMC. It is also highly probable that the stimulation of neuronal motilin receptors is more efficient in the induction of the MMC than the direct action on the smooth muscle. The endocrine pathway can thus be important rather for stimulation of individual phasic contractions. The neurocrine action of motilin is more probable for the induction of phase III of the MMC because of its composed organization and evoking mechanisms. Other neural mechanisms, including those linked with biological clocks, might be engaged as well. It is known that in the postprandial state motilin does not evoke phase III in normal conditions, because its level in the blood is suppressed and its fluctuations in the blood are abolished. When exogenous motilin is supplied during the digestive state, phase III cannot be induced $(125,317)$. Motilin proves to be effective in the modulation of gastric emptying of liquids and solids in man and $\operatorname{dog}(38,53)$. Since phase III is not evoked postprandially in these species, it appears that motilin can trigger the propulsive contractions despite its lowered level in plasma. Endogenous motilin, released in response to morphine administration in the fed state, is suspected to induce phase III (225). The rabbit motilin antiserum did not decrease plasma motilin level completely (18). The duodenectomy also decreased plasma motilin level 
only in part (271). This may further confirm that there is still another pathway for the motilin action and the source of motilin release, since in the postprandial period, nutrients and hormones, such as secretin or pancreatic polypeptide (PP), can hamper motilin-evoked effect $(37,126,172)$. There are several reasons to assume that motilin release from endocrine cells, in response to various regulatory factors, can be amplified by intestinal contractions. It may help to achieve the sufficient motilin level for the induction of phase III of the MMC or for potentiation of motility only (223). The mechanism can be treated as supplementary for endocrine release and action of motilin.

Apart from the endocrine mechanism, there are three other possible mechanisms or groups of mechanisms of motilin release and action.

[A] First possible neural mechanism of motilin release and action is linked to the vagus nerve cooperating with the enteric nervous system. Motilin is present in the vagus (120). The MMC-related plasma motilin fluctuation and motilin release by vagal stimulation were abolished by hexamethonium $(78,150)$. The electrical vagal stimulation increased motilin release (147). Thus, the vagal pathways involved in motilin release comprise primarily the nicotinic receptors (78). On the contrary, vagal stimulation by insulin-dependent hyperglycemia or sham feeding depressed motilin release, at least in dogs (151). Vagal cooling slightly increases motilin levels during fasting. Following vagal blockade, the motilin level and the MMC may remain unchanged (103). The effects of vagotomy are inconsistent, thus, they might be different from those of vagal cooling (103, 151, 323). In man, vagotomy surprisingly increased motilin levels (83). It has also been demonstrated that in fed animals motilin induced phase III of the MMC after vagotomy (173). However, after vagotomy phase III contractions were less potent than before vagotomy (268). These results are still difficult to interpret and it is too speculative to propose to what extent the vagal-dependent mechanisms can operate. The vagus nerve might be involved in the initiation of the MMC and the contribution of motilin to this mechanism is very probable.

[B] The second mechanism responsible for motilin release and action is confined to the cholinergic mechanisms, located in the enteric nervous system. Motilin as well as its receptors are present in the intramural neurons $(78,267)$. The intrinsic excitatory pathways for motilin release involve neural endings with muscarinic receptors present on both motilin cells and the smooth muscles. The electrical stimulation of intrinsic nerves releases motilin (78). Motilin can exert excitatory effect upon the myenteric neurons in the small bowel (130). It has been demonstrated that atropine, unlike hexamethonium, blocked motilin release evoked by the carbachol since the muscarinic receptors are present on the motilin cells (321). Several weeks following vagotomy, motilin fluctuated in accordance with the MMC, exactly as before the surgery, suggesting that the intramural cholinergic neurons might not be important for motilin secretion, at least in the dog (151). In the duodenum, the phase III of the MMC is not always accompanied by motilin peaks, whereas in the jejuno-ileum there is virtually no correlation (223).

[C] A third group of mechanisms is linked to the neuroendocrine pathway of motilindependent control of the MMC. The stimulatory non-adrenergic non-cholinergic (NANC) neurons may thus be engaged, since several endogenous regulators can induce phase III (213, 223). The regulators can initiate phase III of the MMC directly or in cooperation with the motilin-containing neurons. If the group of mechanisms is sufficient to evoke the MMC, the plasma level of motilin can remain unrelated to the induction of the pattern. When exogenous motilin evokes the release of endogenous peptide acting on motilin receptors located on intrinsic neurons, both the preganglionic and postganglionic pathways may contribute to this 
action. It indicates the possible involvement of the enteric nervous system in the endocrine mechanism of motilin release and action (174). Therefore, it can represent a mixed endocrine-neuroendocrine mechanism and the question is raised whether or not a pure endocrine mechanism of motilin release and action exists and if it is sufficient to evoke the MMC. The combined endocrine-neuroendocrine mechanism of motilin release seems to be more efficient in the generation of phase III, since more motilin can be released than in the situation when the enteric nervous system is not involved (124).

The existence of the composed mechanism, governing the induction of phase III by motilin seems very probable because of possible involvement of the relaxation oscillators coupled within the interstitial cells of Cajal and/or within the various types of intrinsic neurons. The neurons are responsible not only for the initiation of phase III but also for the coordination and migration of the whole MMC cycle (223).

Finally, it can be asserted that the role of motilin as the neuromodulator in the initiation of phase III of the MMC seems more probable and important than its rather supportive role as the gut hormone. Motilin action is apparently mediated by central and peripheral neural mechanisms regulating the $\mathrm{MMC}$ and both these groups of mechanisms seem to be important $(40,118,222)$.

\section{Serotonin}

Serotonin (5-hydroxytryptamine, 5-HT) is the omnipresent regulator found in the brain, although about $95 \%$ of the substance occurs within the gastrointestinal tract (137). The principal gastrointestinal 5-HT depot is located in the enterochromaffin cells (87). 5-HT is thus a tissue hormone as well as a neurotransmitter acting within the enteric nervous system, presumably as a member of the NANC system. In various animal species, it exerts stimulatory effects on gastrointestinal motility, including the MMC initiation $(105,192)$. Selective 5-HT reuptake inhibitors reduced the MMC cycling and increased the migration velocity of its phase III in man (93). In rats, the enteric serotonergic neuron destruction decreased the MMC cycle (193). The modulatory action of 5-HT upon the MMC is executed mostly through two 5-HT-receptor subtypes, 5- $\mathrm{HT}_{3}$ and 5-HT $(19,116,273)$. The 5- $\mathrm{HT}_{3}-$ receptor subtype, called the extrinsic receptor, mediates the motility-inducing serotonergic transmission from the gastrointestinal tract to the brain, activating the enteric afferent neurons (87). The extrinsic 5- $\mathrm{HT}_{3}$ receptor, located on vagal afferents, can mediate the initiation of phase III of the MMC from the stomach, both of man and dog, or from the small bowel of the rat, through acetylcholine release and, possibly, through motilin release $(123,161,312)$. $5-\mathrm{HT}_{1}$ - and 5- $\mathrm{HT}_{4}$-receptor subtypes, called intrinsic receptors, enhance the release of the transmitter within the enteric nervous system from the terminals of prokinetic circuits. The receptors are located in the myenteric plexus $(272,273)$. Studies with the specific antagonists in dogs confirmed that $5-\mathrm{HT}_{3}$ receptors are involved in the generation of phase III in the stomach, whereas $5-\mathrm{HT}_{4}$ receptors are involved in the generation of phase III of the MMC in both the stomach and small bowel (180). In the rat's small intestine, the 5- $\mathrm{HT}_{4}$-receptor antagonist inhibited the MMC cycles. The application of 5- $\mathrm{HT}_{3}$-receptor antagonist prolonged the MMC cycle that can represent only the stage leading to the MMC inhibition (11). The 5- $\mathrm{HT}_{1}$ receptor is also involved in the control of the MMC. In man, a 5- $\mathrm{HT}_{1}$-receptor agonist prolonged phase II, while phase I and phase III of the MMC were not affected (33). Since 5-HT can be released into the small intestinal lumen, where it can mediate motilin action, the intravenous 5-HT administration can induce phase III of the MMC in the dog (134, 269). 5-HT released from the enterochromaffin cells, at least in response to the mucosal 
stimuli, acts as the sensor and can activate 5-HT receptors in the gut. It may rather initiate local motility changes than affect the whole MMC cycle thus inducing minor alterations in the upper gastrointestinal tract $(105,277)$. Serotonin, which acts within the myenteric plexus, may directly regulate the gastrointestinal motility including the MMC $(48,81,207)$. It can be synthesized either in the neurons or might be uptaken from the blood.

Taking together, it seems likely that in the interdigestive state, 5-HT can affect the initiation of phase III of the MMC from the stomach in the pathway involving the extrinsic and intrinsic innervations. In the small bowel, it seems to operate mainly within the enteric nervous system. In the action of 5-HT upon the MMC, both 5- $\mathrm{HT}_{3}$ and 5- $\mathrm{HT}_{4}$ receptors are involved, but when the drug activating both 5-HT-receptor subtypes is applied, phase III is not initiated (19). 5-HT can evoke propulsive contractions and it also participates in other motility events. Its action combined with motilin can be more effective. It appears that the 5-HT regulates the MMC principally as a neuromodulator. The prokinetic drugs, especially cisapride, acting mostly through $5-\mathrm{HT}_{3}$ (as an agonist) and $5-\mathrm{HT}_{4}$ (as a weak antagonist) receptors upon the gastrointestinal motility, have been applied as therapeutic agents in the treatment of gastrointestinal disorders $(50,200,266,286)$ though side effects limit their use.

\section{Ghrelin}

Ghrelin is a newer hormone with $36 \%$ of the structural homology to motilin and in man, its receptor resemblance equals $\sim 50 \%$ of overall identity with the motilin receptor (36). However, these hormones have poor crossing affinity to their receptors (i.e., the affinity of ghrelin to motilin receptors and affinity of motilin to ghrelin receptors); thus, the action of each of them is mediated by their own specific receptor. Both hormonal peptides trigger the $\mathrm{MMC}$, at least in the stomach, and stimulate the gastrointestinal motility. Hence, ghrelin was termed the "motilin-related peptide" (284). Ghrelin occurs mainly in the endocrine cells of the stomach (139). It is also present in the duodenal and jejunal mucosa where it can be synthesized and stored with motilin in the same cell (310). Plasma ghrelin level does not fluctuate as clearly as motilin in accordance with the MMC, at least in man, but its level declines after a meal (240). Ghrelin and its receptors are present in the neurons within the myenteric plexus (319). Exogenous ghrelin can induce phase III-like activity in man, but it seems likely that in the natural conditions ghrelin level may be insufficient to induce phase III $(34,264)$. In fasted rats, ghrelin intensified the spontaneous phase III-like contractions or shortened the duodenal cycle length as well as the duration of phase III $(9,300)$. This action was mediated by muscarinic, 5-HT, and nitric oxide receptors. Since ghrelin is present in various gastrointestinal regions, the question arises whether ghrelin contributes to the regulation of the MMC pattern mostly in the endocrine pathway or as a neuromodulator. It is also interesting to what extent its cooperation with motilin is inevitable. It has already been recognized that ghrelin acts not only peripherally, through its receptors located on myenteric neurons, but the predominant pathway of its action is also transmitting the information from the gastrointestinal tract through the vagus nerve to the brain $(10,189$, 190). It was found in rats that ghrelin induces fasting motor activity by activating the neuropeptide $\mathrm{Y}$ neurons in the brain possibly through the ghrelin receptors located on vagal afferent neurons. Its central effect was abolished by vagotomy (82). Furthermore, ghrelin induced phase II of the MMC in Suncus murinus and this response was conducted by vagus nerve (173). During in vitro studies, large doses of ghrelin, given alone, did not stimulate contractions in the gastric preparations of Suncus murinus, but when pretreatment with the low dose of motilin was conducted, ghrelin induced contractions efficiently (176). 
It has been shown to date that the control of the MMC by ghrelin can be exerted in both the extrinsic and intrinsic pathways and ghrelin acts predominantly as a neuromodulator. Cooperation with motilin could be essential, at least in the stimulation of the gastrointestinal contractions, but the effects might be species-dependent.

Figure 1 shows possible MMC-controlling mechanisms involving motilin as the principal neuromodulator with or without cooperation with 5-HT and ghrelin.

\section{Somatostatin}

Somatostatin was found in both the brain and periphery. In the gastrointestinal tract it is synthesized and stored by endocrine D cells that are dispersed mostly in the gastric and duodenal mucosa and also in the remaining gut segments, whereas in the enteric nervous system, it is located in the interneurons of submucosal and myenteric plexuses throughout the

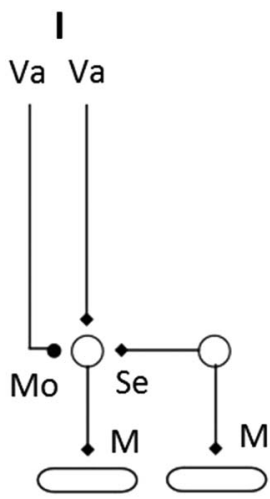

IV

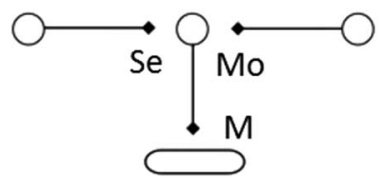

II

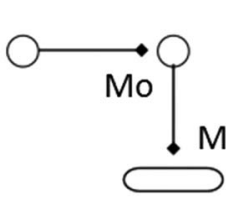

III

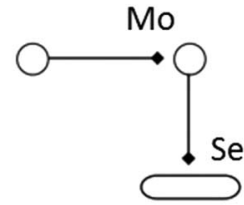

V

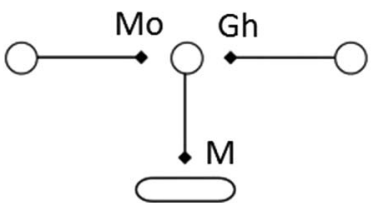

Fig. 1. The postulated controlling mechanisms of the migrating motor complex engaging the motilin as a neuromodulator, with or without cooperation with serotonin (5-HT) and ghrelin. I. Central control of the MMC. Motilin is released within the afferent vagal fibers and evokes central response transmitted through efferent vagal fibers. It affects 5-HT release within the enteric neurons, inducing the stimulatory motor response on the smooth muscle that is finally mediated by cholinergic muscarinic receptors located on the enteric efferents and/or on the smooth muscles. II. Peripheral action of motilin released from the enteric neurons or reaching them from the blood. Final stimulatory motor response on the smooth muscle is mediated by cholinergic muscarinic receptors. This mechanism can be entirely neurocrine or mixed (endocrine-neuroendocrine). III. Peripheral neural stimulatory or inhibitory response of the smooth muscle evoked by 5 -HT whose release is modulated by motilin operating within the interneurons of the enteric nervous system. 5-HT can be released from the enteric neurons or can reach the enteric neurons from the blood. The mechanism can be entirely neurocrine or mixed (endocrine-neuroendocrine). IV. Peripheral neuronal stimulatory response of the smooth muscle induced by 5-HT and amplified by motilin acting within the enteric nervous system. V. Synergistic peripheral neural stimulation of the motor response of the smooth muscle by motilin and ghrelin acting within the enteric neural network. The final response is mediated by cholinergic muscarinic receptors. Mo: motilin; M: muscarinic receptors; Se: 5-HT; Gh: ghrelin;

$$
\bigcirc \text { : enteric ganglion; } \longrightarrow \text { : smooth muscle }
$$


digestive tube, particularly in the small intestine $(49,132,196)$. In the human gut, only about $10 \%$ of somatostatin is located within the muscles and about $90 \%$ in the mucosa (191). However, in the small bowel, somatostatin is mainly located in the neurons within the submucosal and muscle layers (294). Independently of the intrinsic neurons, somatostatin was found in the noradrenergic neurons of the sympathetic ganglia. Their fibers project mainly to the submucosal ganglia of the small bowel and to the regions of vagal nerve ending in the gut $(115,287)$. Various types of somatostatin receptors are distributed within the gut including the enteric nervous system (175). In the gastric antrum and small intestine, but not in the gastric corpus, D cells (the open secretory cells) project to the lumen that enables a paracrine action of somatostatin (143). Acids and a variety of neurohumoral factors can stimulate D cells, whereas acetylcholine inhibits somatostatin release in the D cell-related pathway (61). Since tetrodotoxin and atropine can inhibit somatostatin release, it can be presumed that the actions of some luminal stimuli in the gut may be mediated by nerve endings located on epithelial surface and transmitted to D cells by intrinsic neurons $(99,220)$. Plasma somatostatin fluctuates in accordance with the MMC (285). The effect of somatostatin upon the gastrointestinal motility is complex and mostly inhibitory (320). In the fasting state, its effect upon the MMC, appears to exhibit a dose-dependent character. Somatostatin, applied in smaller doses, shortens the MMC cycles, whereas its higher doses exert inhibitory effects $(27,185,195,282)$. The hormone may locally induce phase III-like activity (114). When the MMC is induced by somatostatin, its phase II is greatly reduced and phase III is ectopic. In these MMC cycles, phase I predominates. Somatostatin can cooperate with motilin in the induction of the MMC in the gut. The occurrence of MMC is not always associated with the motilin peaks since motilin release can be blocked by somatostatin (75). Somatostatin can also contribute to the induction of phase III of the MMC in the postprandial period or after pentagastrin-stimulated fed state $(239,260,282)$. Therefore, the hormone can modulate the MMC, either in the interdigestive or digestive state, and peripheral mechanisms mediating its action seem to involve the enteric nervous system $(117,298)$. Centrally evoked factors may be important in the release and action of somatostatin. It appears that the central nervous system also contributes to the control of the MMC by the hormone or to the modulation of the character of interdigestive and postprandial intestinal motility $(21,56,95)$.

Somatostatin appears to control the gastrointestinal motility, including the MMC, mainly in the peripheral neuroendocrine pathways and the enteric nervous system plays a marked mediatory role in the hormone action. However, contribution of endocrine and paracrine pathways in the regulation of the MMC by somatostatin remains unclear.

\section{Enkephalins}

Natural opioid peptides are known to be active in many regions of the brain and their central action can also comprise the gastrointestinal motility (169). Among known endogenous ligands of the opioid receptors, enkephalins can play a role in the control of the MMC. The role of the opioid mechanism was confirmed with the use of the natural opioid peptides and xenobiotics exerting their effect through the opioid receptors $(228,229)$. The opioid receptors are abundant in the gastrointestinal enteric nervous system, i.e., in the interneurons, although they are also present in the gastrointestinal smooth muscles $(178,236)$. While the $\mu-, \kappa-$, and $\delta$-opioid receptors contribute to the control of gastrointestinal motility, the $\mu$-type receptor is involved in principio in the control of the MMC $(23,94)$. Met-enkephalin is the major regulator of the MMC, whereas Leu-enkephalin is much less active in this area. Since Metenkephalin may exert a presynaptic inhibitory effect on acetylcholine release from the 
myenteric plexus, it seems likely that its interaction with the cholinergic system represents basic mechanisms affecting the gastrointestinal motility by endogenous opioids (296). Opioid peptides exerted inhibitory effect on gastric emptying and intestinal transit, and their action on the smooth muscle contractility was either inhibitory or stimulatory. All the effects were dose- and species-dependent $(23,169)$. The application of enkephalin analogues revealed the substantial contribution of the opioids to the control of the MMC pattern. Met-enkephalin analogue, Dalamide, when administered centrally at a small dose and intravenously at a higher dose, disrupted canine fasting antral and jejunal motor activity for the relatively long time $(23,26)$. In the fed state, another analogue, like morphine, restored the MMC pattern. It appeared to act centrally, even when administered intravenously, since it probably crossed the blood-brain barrier. The described effects of Dalamide, at least on the canine stomach, were mediated by the $\mu$-type opioid receptor $(23,26)$. Similar experiments were performed in rats (206). In fed animals, Dalamide given intracerebroventricularly shortened the postprandial inhibition of the MMC. When Dalamide was administered intraperitoneally, its effect was the opposite. Therefore, in rats a dual route-dependent effect was observed (206). The central action upon the MMC was confirmed with the intracerebroventricular administration of thiorphan, the enkephalinase inhibitor, which disrupted the MMC pattern in dogs for several hours. Thiorphan does not cross the blood-brain barrier and its intravenous administration did not affect the MMC. Leu-enkephalin analogue (DADLE, dominantly $\delta$ opioid receptor agonist) failed to modify the gastrointestinal MMC in both the fasted and fed states.

The scant data suggest that Met-enkephalin affects the MMC through central mechanisms which points to its role as a neuromodulator. Therefore, the contribution of the enteric nervous system to the opioid control of the MMC cannot be excluded. It is also noteworthy that loperamide and diphenoxylate, the exogenous, mainly peripherally acting opioids, are commonly used in the treatment of diarrhea in, for example, numerous settings of the inflammatory bowel disease (104). Loperamide, the $\mu$-receptor agonist, attenuates the intestinal motility, slows transit, and exhibits antisecretory activity that makes it one of the most efficient drugs in the symptomatic treatment of the various types of diarrhea $(12,32$, 184). Loperamide, as a much safer and well-tolerated drug, seems to be superior to diphenoxylate (108). Diphenoxylate is often applied with atropine (276).

Pancreatic polypeptide (PP). PP is a hormone produced, almost exclusively, in endocrine cells of the pancreas (2). PP released from the pancreas can reach the brain through the systemic circulation or can stimulate the PP receptors in the gut. PP is also present in nerves (298). PP acts through specific class of receptors present mainly in the various brain regions $(168,308)$. The binding sites for PP within the brain are located mostly in some cortical, subcortical, hypothalamic, and mesencephalic regions. They are also present in the rhombencephalic areas, especially in nucleus tractus solitarius, area postrema, and dorsal motor nucleus of the vagus $(158,307,308)$. These regions remain in easy contact with the blood. The hormone release is mostly under vagal control, thus it is possible that peripheral cholinergic influences are also implicated in the hormone action $(164,182,248)$. Other mechanisms affecting PP release seem secondary or not important. However, a certain role of motilin in PP action can be postulated (306). PP level in the blood fluctuates in accordance with the MMC in the fasted state and is elevated after the meal $(126,274)$. PP is also released by sham feeding and by other feeding-related procedures $(2,249,274)$. PP receptors may also be present in the gut (88). The hormone increases motor activity in the stomach and small bowel, accelerates gastric emptying, and promotes the intestinal transit (159). It is unlikely 
that these effects are not mediated by the enteric nervous system (237). The data illustrating the effect of PP upon the MMC are inconsistent. As it was found in dog, the moderate dose of PP blocked the MMC in the stomach and upper small intestine, whereas the lower dose was rather ineffective $(102,279)$. Another study on dogs and pigs showed that the higher doses of PP increased the frequency of the MMC (27). In rats, PP inhibited the motility and disrupted the MMC pattern in both the duodenum and the jejunum $(6,241)$. The central effect of PP mediated by vagus seems to be more important in dogs than in rats, while the role of the sympathetic nervous system is negligible $(39,241)$. The effects of PP can be modified by the concomitant alteration of motilin level. The results derived from several reports indicate that PP can act peripherally as the motilin antagonist in the control of gastrointestinal motility including the $\operatorname{MMC}(6,39,102,126,279)$. It does not exclude the possibility of the central action of $\mathrm{PP}$, although the mediatory role of the cholinergic system in the PP control of the MMC still remains unclear.

Finally, it can be proposed that PP regulates the gastrointestinal MMC pattern, possibly in cooperation with motilin, and the mediatory role of the cholinergic mechanisms in the control of MMC by PP is very probable. Central, rather than peripheral cholinergic mechanisms may be principally involved, but the meaningful mediatory role of the enteric nervous system seems to occur as well.

\section{Neurotensin}

Neurotensin is produced in the brain, gastrointestinal nerves, and also in ileal and jejunal mucosa ( $\mathrm{N}$ cells), while its smaller amounts are present in the stomach and in other intestinal regions $(14,64,79,138,198,246)$. Neurotensin receptors are expressed in the brain, gastrointestinal mucosa and submucosa as well as in both the myenteric and submucous plexus $(92,232,250,293)$. Neurotensin can be released postprandially and fat is the most potent stimulus (280). The hormone is released mainly from the gut, since ileal resection can abolish fat-induced neurotensin release (297). As atropine markedly inhibited neurotensin release in man and dog, hormone release appears to be under cholinergic control $(74,77)$. The hormone inhibits the gastrointestinal motility and gastric emptying, but in vitro studies indicated that small doses of the hormone exert stimulatory effects $(133,209)$. These contractions are rather not propulsive. Small doses of neurotensin, injected intraarterially into the small bowel segment, exerted inhibitory effects on canine duodenal and ileal motility (221). Neurotensin may act directly on the smooth muscle, suggesting that the endocrine or neuroendocrine pathways appear to represent important mechanisms underlying the effects $(216,221)$. However, neurotensin inhibited contractile activity, also through neural pathways, releasing norepinephrine that activated primarily $\alpha_{2}$-adrenoceptors that inhibit, in turn, the acetylcholine release. In the small bowel, neurotensin converted the fasting pattern (MMC) into the fed pattern that was observed in men, dogs, and rats $(5,252$, 278). The effect was prevented by vagotomy and the administration of atropine and hexamethonium (4). When neurotensin was inoculated intracerebroventricularly in the fasted state, canine jejunal MMC was replaced by isolated phases of regular activity, whereas neurotensin administered to the fed rats restored the MMC pattern $(22,25)$. Therefore, considering the action on gastrointestinal motility, neurotensin can be called the gut-brain peptide (51).

Neurotensin belongs to the regulators inhibiting the MMC mostly in the neuroendocrine pathway(s). The involvement of the enteric nervous system in the neurotensin action on the cessation of the MMC has not been precisely elucidated, but seems to be very likely. 


\section{Cholecystokinin (CCK)}

CCK occurs in several forms in endocrine I cells, mainly in the jejunum, where it is synthesized and stored $(144,156)$. It is also released from these cells. Furthermore, CCK is synthesized in neurons. CCK-containing neurons are the most common in brain and are also present in the enteric neurons, mostly in the submucosal plexus $(59,84,204)$. The hormone was identified in the myenteric neurons as well, especially as CCK octapeptide $(145,246)$. CCK exerts its action after binding with specific receptors present in neuronal and nonneuronal tissues. Within the nervous system, CCK receptors were found in the brain and vagus nerve $(119,257,324)$. CCK receptors are also expressed by the gastrointestinal tissue (298). Principally, two CCK receptors were recognized, CCK-A $\left(\mathrm{CCK}_{1}\right)$ and CCK-B/gastrin $\left(\mathrm{CCK}_{2}\right)$, both present in the nervous system and the gastrointestinal tract. CCK-A receptor exhibits high affinity to CCK. It was identified in the pylorus, vagus nerve, enteric neurons, and in the central nervous system. CCK-B receptor exhibits lower affinity to CCK. It mostly occurs in the stomach and central nervous system $(61,183)$. CCK can act through both receptors. It is released from endocrine cells directly by food and food components, like some fatty acids and few types of amino acids, or by some CCK-releasing putative luminal factors $(110,111,140,157,167,256)$. Apart from various actions of CCK, some of its effects on the gastrointestinal motility appear to be physiological. The hormone exerts stimulatory effects on various parts of the stomach, but inhibits gastric emptying due to the relaxation of its proximal part and the contraction of the pylorus $(52,86,322)$. Moreover, CCK stimulates small intestinal motility and shortens the intestinal transit. However, there are no data showing that CCK evokes propulsive contractions $(101,154)$. In the fasting state, CCK causes the disruption of the MMC, at least in the dog. Following CCK administration and MMC inhibition, the character of alternative motility, which replaces the MMC, does not resemble the fed pattern and plasma motilin cycling is preserved $(179,315)$. In rats, endogenous CCK also disrupted the MMC (208). The mechanism of CCK action on the gastrointestinal motility is complex. CCK-A receptor occurs in the vagal afferents and CCK can stimulate it in the stomach, thus affecting both the motility and emptying $(202,247)$. Modulation of gastric motility by CCK in the endocrine pathway is possible, but it has also been demonstrated that CCK activates vago-vagal reflexes in the gut (61). The neural mechanisms of CCK action on small intestinal motility appear to predominate. CCK induces contractions of the circular muscle layer and inhibits contractions of the longitudinal muscle layer (258). The effects are antagonized by atropine, hexamethonium, and depolarizing doses of nicotine, which suggest that CCK activates cholinergic receptors on postganglionic cholinergic neurons in the gut. In the isolated gastroduodenal preparations, CCK induced motor activity in the neural pathway and also induced contractions, acting directly on the muscle (238). In the isolated gastric smooth muscle cells, CCK induced contractions as well (44). Responses to nutrients, mediated by $\mathrm{CCK}$, are also transmitted through the neural pathway (66). The delay or disruption of the MMC by CCK can be regulated centrally (21). The endogenous CCK can act on vagal-afferent CCK-B receptors to stimulate central CCK-A receptor to disrupt the MMC (208). Furthermore, low doses of CCK applied in the autotransplanted proximal gastric pouches, effectively inhibited normal interdigestive cycles (234). The effect was local, although it is uncertain whether it occurred in the neural pathway.

Thus, CCK can centrally control the gastrointestinal motility, including the MMC pattern, but the enteric neural mechanisms are also engaged. The involvement of endocrine pathways, mediating the effects of CCK upon the gastrointestinal motility, is possible, although their role in the control of the MMC is doubtful. 


\section{Gastrin}

The natural gastrin mostly occurs as a heptadecapeptide, G17 (sulfated and non-sulfated) and also as G34, while little is known about the physiological role of other gastrin forms like G14 or G71 (61). Pentagastrin is the common exogenous form of gastrin exhibiting full gastrin activity. Gastrin is synthesized and released from the $\mathrm{G}$ cells distributed mostly in the pyloric antrum and also in the duodenum. Small amounts of gastrin are present in the vagus nerve and pituitary $(203,288)$. The presence of gastrin in the brain is uncertain $(61)$. Multiple gastrin actions are mediated by specific receptors, i.e., almost exclusively by the $\mathrm{CCK}-\mathrm{B} /$ gastrin receptor, since the affinity of the gastrin to CCK-A receptor is approximately 1,000 times smaller than that of CCK (298). Gastrin is released by food and by elevation of gastric $\mathrm{pH}$, while strong acidification inhibits gastrin release. Some nutrients, such as peptides and amino acids, enhance gastrin release (299). Calcium, neural reflexes, and circulating catecholamines represent other releasing factors. The role of the nervous system, i.e., cholinergic enteric neurons and vagus nerve in gastrin release, is complex and important. Among other hormones, the bombesin-like peptide, namely the gastrin-releasing peptide (GRP), also called the mammalian bombesin, can increase gastrin release from its endocrine stores (244). GRP release is mediated by the neural pathway. Within the gastrointestinal tract, gastrin receptors are expressed by both the gastric parietal cells and the enterochromaffin cells, and some by the smooth muscle cells. They are also present in the neurons of the central and peripheral nervous system (61). Gastrin effect upon the gastrointestinal motility is rather stimulatory (298). It increases gastric antral contractions in vitro and in vivo, although in the proximal stomach, its effect is inhibitory that could be associated with concomitant somatostatin release $(135,177,245,298,311)$. Gastrin slows gastric emptying despite the initiation of propulsive types of contractions in the distal stomach. Decreasing the intragastric pressure can be one of the reasons of this response $(46,135)$. Gastrin also stimulates the intestinal motility $(253,295)$. In many cases, gastrin appears to exert its effect upon the gastrointestinal motility acting directly on the smooth muscle (298). It was found that pentagastrin excited antral longitudinal muscle by the release of acetylcholine and directly stimulated the circular muscle layer (261). In the guinea pig ileum, it acted through the neural mechanisms since the motor response was abolished by tetrodotoxin and attenuated by atropine (295). Gastrin also disrupts the MMC pattern that was demonstrated clearly in the dog, although it does not seem to reproduce the fed pattern $(68,163,304)$. The disruption of the interdigestive pattern was also observed after bilateral vagotomy (163). However, when pentagastrin infusion was stopped in vagotomized dogs, the MMC was initiated again in the stomach and the duodenum. Therefore, it can be assumed that gastrin can inhibit the initiation of the MMC from the stomach and the duodenum, acting directly on the smooth muscle. Possible involvement of central mechanisms in the changes in the MMC, evoked by gastrin, cannot however be excluded. Since both feeding and sham feeding strongly evoke gastrin release, the hormone contributes to the inhibition of MMC by food. Gastrin release is mediated by the vagus nerve and this response was found to be resistant to atropine administration $(62,275)$.

In summary, gastrin participates in the postprandial MMC inhibition, though its precise mechanism of action is still uncertain. Although gastrin receptors are sparse in the gastrointestinal nerves and only few gastrin cells are in the gut, the role of endocrine mechanism in the inhibition of the MMC by gastrin is possible, while the data indicating the involvement of neural mechanisms are also available. 


\section{Conclusions}

Several neuropeptides and other regulators, members of the NANC system, contribute to the control of the MMC within the enteric nervous system $(60,61,72)$. The best recognized regulators were discussed earlier and characterized in Table I. Apart from the hormonal factors described earlier there are some others which can also participate in the control of the MMC (106, 213), but little is known concerning their distribution, receptor localization, and mechanism of action. Considering the presented major hormonal regulators of the MMC pattern, it can be concluded that the neural mechanisms predominate in their action on the gastrointestinal motility and all the factors may influence the MMC through the central and/or peripheral neural controlling pathways. Therefore, they can regulate the MMC mostly as neuromodulators. Their influence through the endocrine and paracrine pathways may concern rather the initiation and modification of the individual contractions, including the contractions occurring within the MMC cycle. Indeed, these factors induce or disrupt the phase III of the cycle, but in this respect their direct action on the smooth muscle appears less important. They do not seem to be responsible for the migration of phase III and for the whole cycle along the bowel. It is unwarrantable to assert that the MMC can migrate without the contribution of the enteric nervous system. Furthermore, the initiation and migration of the MMC may require the engagement of relaxation oscillators, apparently linked to the enteric nervous system, since some enteric neurons may contain an internal clock (224). The distribution of chemical regulators in the gastrointestinal tract and distribution of their receptors are variable and there are several important species differences. The variabilities hindered the understanding of the regulators' contribution in the control of the MMC cycles, especially of those confined to the endocrine and paracrine pathways. Luminal chemical factors appear to be directly responsible for the initiation of the MMC. The hormone-dependent induction of phase III may occur in one locus, although other mechanisms might be responsible for the migration of phase III or for the organization and migration of the MMC along the gut. Some chemical factors responsible for the cessation of the MMC also seem to act in cooperation with the nervous system. These substances may not be widely distributed throughout the gastrointestinal tract and they are thus able to achieve sufficient concentration only in a relatively short bowel segment. Their physiological role in the control of the MMC has not been well recognized, but they can finally act rather as neuromodulators or neurotransmitters than as hormones.

Figure 2 illustrates the possible pathways engaged in the control of the MMC by chemical factors.

\section{The Role of Intrinsic Innervation in the Control of the MMC}

\section{MMC initiation}

Itoh et al. (124) and Ormsbee et al. (187) prepared dogs with Thiry-Vella intestinal loops and found that MMC cycling within the loop is not related to its cycling in the rest of the bowel. Both the vagal cooling at the thoracic level and vagotomy did not block the MMC arrival in the gut $(90,272)$. The duodenojejunectomy inhibited the MMC in the stomach (270). Finally, close intraarterial injections of atropine and hexamethonium into the small intestinal segment exerted the inhibitory effect on the MMC within and beyond this segment (227). All the results indicate the meaningful role of the enteric innervation in the initiation and maintenance of the MMC in the stomach and small bowel. When the MMC is triggered centrally, the enteric nerves have to mediate this signal. The MMC, as a rhythmic phenomenon, can be 


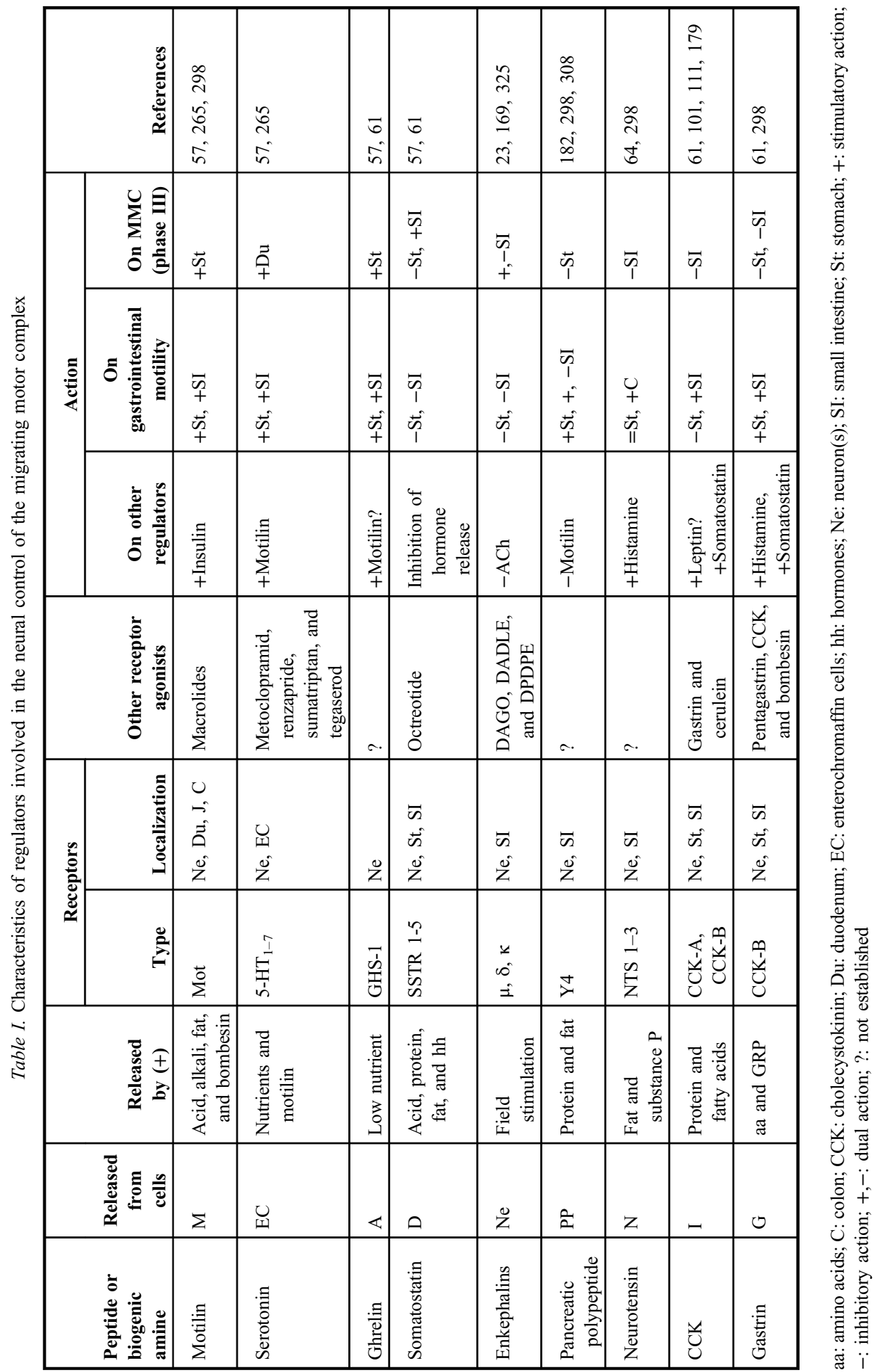




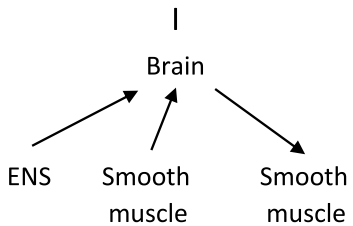

III

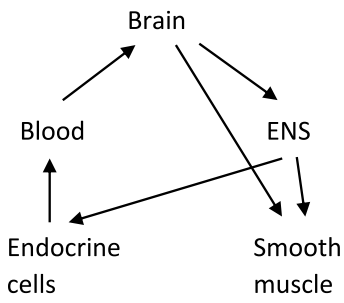

II

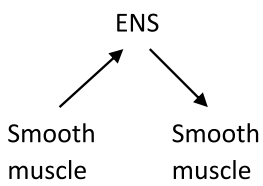

IV

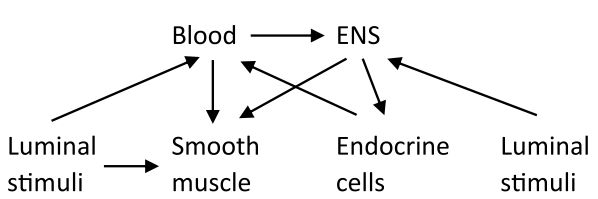

Fig. 2. Scheme presenting possible neurocrine and neuroendocrine pathways involved in the control of the migrating motor complex. I. Extrinsic neurocrine pathway. Neuromodulator is released from the enteric ganglia in response to smooth muscle contraction or relaxation, or to other signals. Then, the neuromodulator affects the brain centers evoking the response sent through the efferent fibers (preferentially the vagus nerve). II. Intrinsic neurocrine pathway. The neuromodulator is released from the enteric ganglia spontaneously or in response to the signals from the smooth muscle. Then, the neuromodulator elicits the smooth muscle contractile response. III. Extrinsic neuroendocrine pathway. The hormonal neuromodulator is released to the blood from the endocrine cells in response to the local (e.g., luminal) stimuli or signals from the enteric ganglia. Then, the neuromodulator evokes central response returned (preferentially by the vagus nerve) either to the enteric ganglia and then to the smooth muscle or directly from the brain to the smooth muscle eliciting final contractile response. IV. Intrinsic neuroendocrine pathway. The hormonal neuromodulator is released to the blood from endocrine cells in response both to the local (e.g., luminal) stimuli and signals from the enteric ganglia. Then, the neuromodulator evokes the contractile effect of the smooth muscle. The neuromodulator can also originate from the lumen and act on the enteric nerves or directly on the smooth muscle

triggered continuously by the central metronome $(113,171,326)$. Thus, both central and peripheral initiation of the MMC appears to be equally important.

\section{MMC migration (maintenance)}

The arrival and migration of the MMC along the gastrointestinal tract may be dependent on the activity of the series of relaxation oscillators that might be located rather in the enteric nervous system along with the clock genes $(223,224,313)$. Thus, melatonin might be suspected to continue its central role in the periphery as well $(166,281)$. The peripheral mechanism can be directly responsible for the migration of the MMC along the bowel. It well explains the occurrence of ectopic fronts and of rebound-type responses observed following the atropine or hexamethonium administration. When the response exhibited the migratory character, it resembled phase III of the MMC. When it was stationary and prolonged, it was clearly different from phase III $(30,142,210,211,214,219,283,289)$. However, the stationary phase III of the MMC can also occur, but it does not seem to be the normal motility pattern. Furthermore, atropine and hexamethonium are able to inhibit phasic contractions, thus blocking the contractile mechanisms which also affect the MMC (230). The results confirmed the importance of the enteric nervous system in the control of the MMC. When the intestinal transection, followed by reanastomosis, was performed, both intrinsic neural and, 
perhaps also, vagal connections were damaged (226). The small bowel was divided into the smaller segments and each of them exhibited the presence of independent MMC. About 2-3 months following surgery, the coordination between the MMCs present in the segments gradually returned. Thus, the enteric nervous system was primarily responsible for restoring the coordination and for MMC maintenance.

\section{MMC cessation}

The experiments demonstrating the existence of the cephalic phase of the MMC control provide an evidence for a central inhibition of the $\operatorname{MMC}(55,199)$. When several hormones like gastrin, CCK, PP (see above), and secretin or insulin are released by feeding, they disrupt the MMC in the same way as food does, but their precise mechanism of action is unclear (223). It is difficult to discriminate between the endocrine and neurocrine actions of these hormones. However, both mechanisms are possibly involved, although the endocrine pathway of MMC inhibition is less probable since its receptors are not always present on the smooth muscles or their density may not be sufficient. These receptors are often stimulatory with respect to the gastrointestinal motility. In addition, the smooth muscles appear to be rather an executory than an initiatory organ regarding the arrival of the MMC pattern. Thus, the hormones can possibly stimulate or inhibit in this way only the individual contractions, not the whole MMC pattern for which more composed mechanism might be desired. The neurocrine pathway may require smaller amounts of the hormone and the regulatory substances can act locally, directly on the intestinal oscillator (109). It is possible that food or nutrients can directly stimulate the release of the hormones (15). The mucosal receptors are sensitive to the nutrients and mechanical stimuli. They transmit signals to the enteric nervous system directly or through the mediatory substances released from the mucosa. Finally, various mediators operate within the enteric neurons in response to mucosal signals $(1,24,47,73,80,160,181,201)$. Therefore, it is possible that not only chemical or mechanical factors, but also the intrinsic nerves participate in the cessation of the MMC.

\section{The Overall Control of the MMC}

The nervous system appears to predominate in the control of the MMC (57). The MMC seems to be initiated centrally all the time, but the local mechanisms decide about its occurrence in the gastrointestinal tract. When the central oscillator is blocked, the MMC cycle can be initiated by the gastric or upper enteric oscillator. In the case when the upper enteric oscillator cannot be active, the lower oscillator initiates the MMC, while the subsequent oscillators are responsible for the migration of the MMC down, along the bowel. It is possible that once a given oscillator is stimulated, it stimulates the next one and so forth (314). The mechanism can also be engaged when the ectopic front occurs. When the MMC returns sometimes after feeding, its phase III is usually ectopic (71). In this situation, the upper oscillators remain inactive and the first activated oscillator represents one of the lower oscillators. It means that the lower oscillators are more reactive than the upper oscillator. The event can be explained by the different sensitivities of the intestinal segments to the factors initiating and disrupting the MMC. It is possible that the role of the central oscillator is to facilitate the MMC occurrence in the gastrointestinal tract, whereas the peripheral oscillator is responsible for its final initiation and migration. In all or almost all the MMC-controlling 

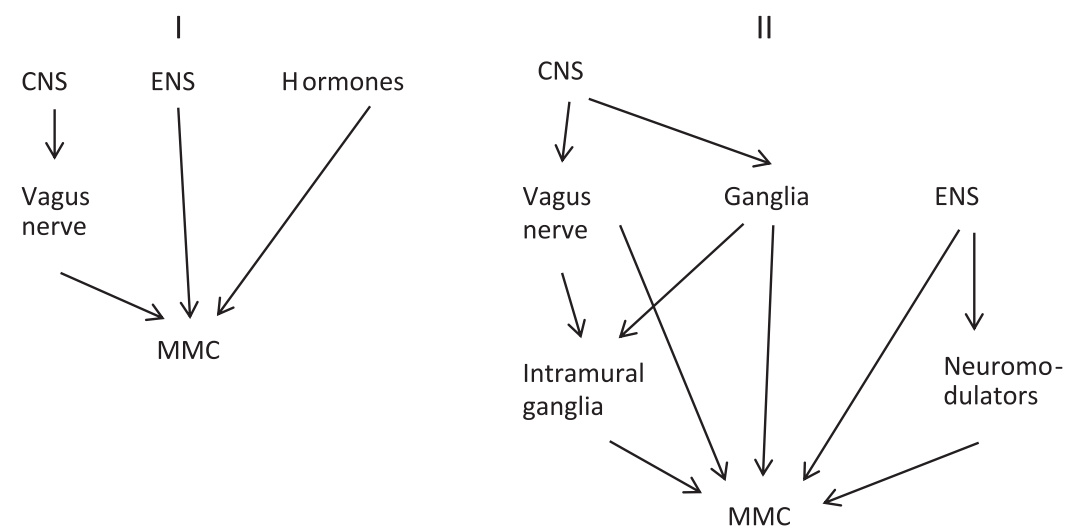

Fig. 3. The overall control of the migrating motor complex. I. The older concept. Three main groups of the controlling mechanisms can be distinguished (223): central neural, peripheral neural, and hormonal. II. The newer concept. Two main groups of controlling mechanisms can be distinguished. Central neural control mechanisms can involve the vagus nerve or not, but both these subgroups of mechanisms engage the enteric nervous system as well. Peripheral neural control mechanisms involve the enteric nervous system as neurocrine pathway or enteric nervous system and endocrine cells as neuroendocrine pathway. Hormonal mechanisms appear meaningful in the control of the individual contractions, not of the MMC pattern as a whole

mechanisms the enteric nervous system is involved. Accordingly, the chemical factors regulating the MMC, can act primarily in the neuroendocrine pathway. It could be really difficult to identify a pure hormonal mechanism controlling the MMC. Even the hormones released from the endocrine cells and acting in the paracrine route may exert their effect rather through neural mechanisms. There are some marked regional differences in the regulatory mechanisms. For example, motilin induces the MMC from the stomach, but somatostatin exerts a stronger effect on the MMC in the small bowel. The role of other hormones may also be different in various parts of the digestive tract. While neurotensin converts the MMC to the fed pattern, CCK and gastrin contribute only to the MMC inhibition. It seems likely that the local mechanisms determine mainly the character of the variabilities within the MMC and some species differences. It is finally asserted that the peripheral neural mechanisms, linked to the enteric nervous system, are crucial in the control of the MMC. However, central MMCcontrolling mechanisms cannot be disregarded, though the complicity of peripheral mechanisms controlling the MMC is required for their normal functioning. Figure 3 presents possible routes and mechanisms active in the overall control of the MMC.

Since the mechanisms controlling the MMC are still incompletely understood, the future progress will mostly depend upon the application of more composed and precise techniques.

\section{REFERENCES}

1. Accarino AM, Azpiroz F, Malagelada J-R: Gut perception in humans is modulated by interacting gut stimuli. Am. J. Physiol. 282, G220-G225 (2002)

2. Adrian TE, Bloom SR, Bryant MG, Polak JM, Heitz P, Barnes AJ: Distribution and release of human pancreatic polypeptide. Gut 17, 940-944 (1976)

3. Ahluwalia NK, Thompson DG, Barlow J, Heggie L: Human small intestinal contractions and aboral traction forces during fasting and after feeding. Gut 35, 625-630 (1994) 
4. Al-Saffar A: Analysis of the control of intestinal motility in fasted rats with special reference to neurotensin. Scand. J. Gastroenterol. 19, 422-428 (1984)

5. Al-Saffar A, Rosell S: Effects of neurotensin and neurotensin analogues on the migrating myoelectrical complexes in the small intestine of rats. Acta Physiol. Scand. 112, 203-208 (1981)

6. Al-Saffar A, Tatemoto K (1984): Effect of peptide YY and porcine pancreatic polypeptide on migrating myoelectric complexes in the small intestine of the rat. In: Gastrointestinal Motility, ed Roman C, MTP Press Ltd., Lancaster, pp. 215-222

7. Altaparmakov I, Wienbeck M (1982): Adrenergic control of interdigestive migrating myoelectric complex (IDMEC). In: Motility of the Digestive Tract, ed Wienbeck M, Raven Press, New York, pp. 193-199

8. Andrews JM, O'Donovan DG, Hebbard GS, Malbert CH, Doran SM, Dent J: Human duodenal phase III migrating motor complex activity is predominantly antegrade, as revealed by high-resolution manometry and colour pressure plots. Neurogastroenterol. Motil. 14, 331-338 (2002)

9. Ariga H, Tsukamoto K, Chen C, Mantyh C, Pappas TN, Takahashi T: Endogenous acyl ghrelin is involved in mediating spontaneous phase III-like contractions of the rat stomach. Neurogastroenterol. Motil. 19, 675-680 (2007)

10. Avau B, Carbone F, Tack J, Depoortere I: Ghrelin signaling in the gut, its physiological properties, and therapeutic potential. Neurogastroenterol. Motil. 25, 720-732 (2013)

11. Axelsson L-G, Wallin B, Gillberg P-G, Sjöberg B, Södeberg C, Hellström PM: Regulatory role of 5-HT and muscarinic receptor antagonists on the migrating myoelectric complex in rats. Eur. J. Pharmacol. 467, 211-218 (2003)

12. Awouters F, Megens A, Verlinden M, Schuurkes J, Niemegeers C, Janssen PA: Loperamide. Survey of studies on mechanism of its antidiarrheal activity. Dig. Dis. Sci. 38, 977-995 (1993)

13. Aytuğ N, Giral A, Imeryüz N, Enç FY, Bekìroğlu N, Aktaş G, Ulusoy NB: Gender influence on jejunal migrating motor complex. Am. J. Physiol. 280, G255-G263 (2001)

14. Barber DL, Buchan AM, Leeman SE, Soll AH: Canine enteric submucosal cultures: transmitter release from neurotensin-immunoreactive neurons. Neuroscience 32, 245-253 (1989)

15. Behrns KE, Sarr MG: Duodenal nutrients inhibit canine jejunal fasting motor patterns through a hormonal mechanism. Dig. Dis. Sci. 39, 1665-1671 (1994)

16. Beyak MJ, Bulmer DCE, Jiang W, Keating C, Rong W, Grundy D (2006): Extrinsic sensory afferent nerves innervating the gastrointestinal tract. In: Physiology of the Gastrointestinal Tract, ed Johnson LR, Elsevier, Amsterdam, pp. 685-725

17. Björnsson ES, Abrahamsson H: Interdigestive gastroduodenal manometry in humans. Indication of duodenal phase III as a retroperistaltic pump. Acta Physiol. Scand. 153, 221-230 (1995)

18. Borody TJ, Byrnes DJ, Titchen DA: Migrating myoelectric complexes and motilin in the dog. J. Physiol. (Lond.) 320, 62P-63P (1981)

19. Briejer MR, Akkermans LMA, Schuurkes JAJ: Gastrointestinal prokinetic benzamides: the pharmacology underlying stimulation of motility. Pharmacol. Rev. 47, 631-651 (1995)

20. Brown JC, Dryburgh JR (1978): Isolation of motilin. In: Gut Hormones, ed Bloom SR, Churchill Livingstone, Edinburgh, pp. 327-331

21. Buéno L, Ferre J-P: Central regulation of intestinal motility by somatostatin and cholecystokinin-octapeptide. Science 216, 1427-1429 (1982)

22. Bueno L, Ferré JP, Fioramonti J, Honde C: Effects of intracerebroventricular administration of neurotensin, substance P and calcitonin on gastrointestinal motility in normal and vagotomized rats. Regul. Pept. 6, 197-205 (1983)

23. Buéno L, Fioramonti J (1985): Enkephalinergic control of the gastro-intestinal motility. In: Small Intestinal and Colonic Motility, ed Poitras P, Jouveinal Laboratories/Laboratories Inc., Montreal, pp. 25-34

24. Buéno L, Fioramonti J, Delvaux M, Frexinos J: Mediators and pharmacology of visceral sensitivity: from basis to clinical investigations. Gastroenterology 112, 1714-1743 (1997)

25. Buéno L, Fioramonti J, Fargeas MJ, Primi MP: Neurotensin: a central neuromodulator of gastrointestinal motility in the dog. Am. J. Physiol. 248, G15-G19 (1985)

26. Buéno L, Fioramonti J, Hondè C, Fargeas MJ, Primi MP: Central and peripheral control of gastrointestinal and colonic motility by endogenous opiates in conscious dogs. Gastroenterology 88, 549-556 (1985)

27. Buéno L, Fioramonti J, Rayner V, Ruckebusch Y: Effects of motilin, somatostatin and pancreatic polypeptide on the migrating myoelectric complex in pigs and dogs. Gastroenterology 82, 1395-1402 (1982)

28. Buéno L, Fioramonti J, Ruckebusch Y: Rate of flow and digesta and electrical activity of the small intestine in dogs and sheep. J. Physiol. (Lond.) 249, 69-85 (1975) 
29. Buéno L, Fioramonti J, Ruckebusch Y: Mechanisms of propulsion in the small intestine. Ann. Rech. Vét. 8, 293-301 (1977)

30. Buéno L, Ruckebusch Y: Effect of anticholinergic drugs on the electrical activity of the antrum and duodenojejunum in sheep. J. Vet. Pharmacol. Ther. 1, 225-232 (1978)

31. Buéno L, Ruckebusch Y (1978): Migrating myoelectric complexes: disruption, enhancement and disorganization. In: Gastrointestinal Motility in Health and Disease, ed. Duthie HL, MTP Press Ltd., Lancaster, pp. 83-91

32. Callahan MJ: Irritable bowel syndrome neuropharmacology. A review of approved and investigational compounds. J. Clin. Gastroenterol. 35(Suppl. 1), S58-S67 (2002)

33. Calvert EL, Whorwell PJ, Houghton LA: Inter-digestive and post-prandial antro-pyloro-duodenal motor activity in humans: effect of 5-hydroxytryptamine 1 receptor agonism. Aliment. Pharmacol. Ther. 19, 805-815 (2004)

34. Camilleri M, Papathanasopoulos A, Odunsi ST: Actions and therapeutic pathways of ghrelin for gastrointestinal disorders. Nat. Rev. Gastroenterol. Hepatol. 6, 343-352 (2009)

35. Carlson GM, Bedi BS, Code CF: Mechanism of propagation of intestinal interdigestive myoelectric complex. Am. J. Physiol. 222, 1027-1030 (1972)

36. Chen CY, Tsai CY: Ghrelin and motilin in the gastrointestinal system. Curr. Pharm. Res. 18, 4755-4765 (2012)

37. Christofides ND, Bloom SR, Besterman HS, Adrian TE, Ghatei MA: Release of motilin by oral and intravenous nutrients in man. Gut 20, 102-106 (1979)

38. Christofides ND, Modlin IM, Fitzpatrick ML, Bloom SR: Effect of motilin on the rate of gastric emptying and gut hormone release during breakfast. Gastroenterology 76, 903-907 (1979)

39. Chung SA, Greenberg GR, Diamant NE: Relationship of postprandial motilin, gastrin, and pancreatic polypeptide release to intestinal motility during vagal interruption. Can. J. Physiol. Pharmacol. 70, 1148-1153 (1992)

40. Chung SA, Rotstein O, Greenberg GR, Diamant NE: Mechanisms coordinating gastric and small intestinal MMC: role of extrinsic innervation rather than motilin. Am. J. Physiol. 267, G800-G809 (1994)

41. Clerc N, Furness JB: Intrinsic primary afferent neurons of the digestive tract. Neurogastroenterol. Motil. 16(Suppl. 1), 24-27 (2004)

42. Code CF, Marlett JA: The interdigestive myo-electric complex of the stomach and small bowel of dogs. J. Physiol. (Lond.) 246, 289-309 (1975)

43. Code CF, Schlegel JF (1973): The gastrointestinal interdigestive housekeeper: motor correlates of the interdigestive myoelectric complex of the dog. In: Proceedings of the 4th International Symposium on GI Motility, ed Daniel EE, Mitchell Press, Vancouver, pp. 631-634

44. Collins SM, Gardner JD: Cholecystokinin-induced contraction of dispersed smooth muscle cells. Am. J. Physiol. 243, G497-G504 (1982)

45. Collins SM, Lewis TD, Fox JET, Track NS, Meghji MM, Daniel EE: Changes in plasma motilin concentration in response to manipulation of intragastric and intraduodenal contents in man. Can. J. Physiol. Pharmacol. 59, 188-194 (1981)

46. Cooke AR, Chvasta TE, Weisbrodt NW: Effect of pentagastrin on emptying and electrical and motor activity of the dog stomach. Am. J. Physiol. 223, 934-938 (1972)

47. Cooke HJ, Christofi FL (2006): Enteric neural regulation of mucosal secretion. In: Physiology of the Gastrointestinal Tract, ed Johnson LR, Elsevier, Amsterdam, pp. 737-762

48. Costa M, Furness JB, Cuello AC, Verhofstad AAJ, Steinbusch HWJ, Elde RP: Neurons with 5-hydroxytryptaminelike immunoreactivity in the enteric nervous system: their visualization and reactions to drug treatment. Neuroscience 7, 351-363 (1982)

49. Costa M, Patel Y, Furness JB: Evidence that some intrinsic neurons of the intestine contain somatostatin. Neurosci. Lett. 6, 215-223 (1977)

50. Crowell MD, Mathis C, Schetter VA, Yunus T, Lacy BE: The effects of tegaserod, a 5-HT receptor agonist, on gastric emptying in a murine model of diabetes mellitus. Neurogastroenterol. Motil. 17, 738-743 (2005)

51. Daniel EE, Sakai Y, Jury J, Fox JET (1982): Mode of action of neurotensin on gastrointestinal motility. In: Motility of the Digestive Tract, ed Wienbeck M, Raven Press, New York, pp. 451-459

52. Debas HT, Farooq O, Grossman MI: Inhibition of gastric emptying is a physiologic action of cholecystokinin. Gastroenterology 68, 1211-1217 (1975)

53. Debas HT, Yamagishi T, Dryburgh JR: Motilin enhances gastric emptying of liquids in dogs. Gastroenterology 73, 777-780 (1977)

54. Defilippi C: Canine small bowel motor activity in response to intraduodenal infusion of nutrient mixtures of increasing caloric load in dogs. Dig. Dis. Sci. 48, 1482-1485 (2003)

55. Defilippi C, Valenzuela JE: Sham feeding disrupts the interdigestive motility complex in man. Scand. J. Gastroenterol. 16, 977-979 (1981) 
56. De Graf J, Woussen-Colle MC: Effects of sham feeding, bethanechol, and bombesin on somatostatin release in dogs. Am. J. Physiol. 248, G1-G7 (1985)

57. Deloose E, Janssen P, Depoortere I, Tack J: The migrating motor complex: control mechanisms and its role in health and disease. Nat. Rev. Gastroenterol. Hepatol. 9, 271-285 (2012)

58. De Wever I, Eeckhout C, Vantrappen G, Hellemans J: Disruptive effect of test meals on interdigestive motor complex in dogs. Am. J. Physiol. 235, E661-E665 (1978)

59. Dockray GJ: Immunochemical evidence of cholecystokinin-like peptides in brain. Nature 264, 568-570 (1976)

60. Dockray GJ (1994): Physiology of enteric neuropeptides. In: Physiology of the Gastrointestinal Tract, ed Johnson LR, Elsevier, Amsterdam, pp. 169-209

61. Dockray GJ (2006): Gastrointestinal hormones: gastrin, cholecystokinin, somatostatin, and ghrelin. In: Physiology of the Gastrointestinal Tract, ed Johnson LR, Elsevier, Amsterdam, pp. 91-120

62. Dockray GJ, Tracy HJ: Atropine does not abolish cephalic vagal stimulation of gastrin release in dogs. J. Physiol. (Lond.) 306, 473-480 (1980)

63. Dooley CP, Di Lorenzo C, Valenzuela JE: Variability of migrating motor complex in humans. Dig. Dis. Sci. 37 , 723-728 (1992)

64. Doyle H, Greeley GH Jr, Mate L, Sakamoto T, Townsend CM Jr, Thompson JC: Distribution of neurotensin in canine gastrointestinal tract. Surgery 97, 337-341 (1985)

65. Dreznik Z, Meininger TA, Barteau JA, Brocksmith D, Soper NJ: Effect of ileal oleate on interdigestive intestinal motility of the dog. Dig. Dis. Sci. 39, 1511-1518 (1994)

66. Eastwood C, Maubach K, Kirkup AJ, Grundy D: The role of endogenous cholecystokinin in the sensory transduction of luminal nutrient signals in the rat jejunum. Neurosci. Lett. 254, 145-148 (1998)

67. Edelbroek M, Horowitz M, Dent J, Sun WM, Malbert C, Smout A, Akkermans L: Effect of duodenal distention on fasting and postprandial antropyloroduodenal motility in humans. Gastroenterology 106, 583-592 (1994)

68. Eeckhout C, De Wever I, Peeters T, Hellemans J, Vantrappen G: Role of gastrin and insulin in postprandial disruption of migrating complex in dogs. Am. J. Physiol. 235, E666-E669 (1978)

69. Eeckhout C, De Wever I, Vantrappen G (1980): Effect of glucose perfusions on the migrating complex of a Thiry-Vella loop. In: Gastrointestinal Motility, ed Christensen J, Raven Press, New York, pp. 289-293

70. Eeckhout C, De Wever I, Vantrappen G: Intestinal motility after infusion of arachis oil into duodenum and ileum of dogs. Dig. Dis. Sci. 29, 164-170 (1984)

71. Eeckhout C, De Wever I, Vantrappen G, Janssens J: Local disorganization of interdigestive migrating complex by perfusion of a Thiry-Vella loop. Am. J. Physiol. 238, G509-G513 (1980)

72. Englander EW, Greeley GH Jr (2006): Postpyloric gastrointestinal peptides. In: Physiology of the Gastrointestinal Tract, ed Johnson LR, Elsevier, Amsterdam, pp. 121-159

73. Feinle C, Grundy D, Fried M: Modulation of gastric distension-induced sensations by small intestinal receptors. Am. J. Physiol. 280, G51-G57 (2001)

74. Feurle GE, Baca I, Knauf W: Atropine depresses release of neurotensin and its effect on the exocrine pancreas. Regul. Pept. 4, 75-82 (1982)

75. Fioramonti J, Buéno L: Hormonal control of gut motility in ruminants and non-ruminants and its nutritional implications. Nutr. Res. Rev. 1, 169-188 (1988)

76. Fleckenstein P: Migrating electrical spike activity in the fasting human small intestine. Dig. Dis. 23, 769-775 (1978)

77. Fletcher DR, Shulkes A, Bladin PHD, Hardy KJ: The effect of atropine on bombesin and gastrin releasing peptide stimulated gastrin, pancreatic polypeptide and neurotensin release in man. Regul. Pept. 7, 31-40 (1983)

78. Fox JET, Daniel EE, Jury J, Track N, Chiu S: Cholinergic control mechanisms for immunoreactive motilin release and motility in the canine duodenum. Can. J. Physiol. Pharmacol. 61, 1042-1049 (1983)

79. Frigerio B, Ravazola M, Ito S, Buffa R, Capella C, Solcia E, Orci L: Histochemical and ultrastructural identification of neurotensin cells in the dog ileum. Histochemistry 54, 123-131 (1977)

80. Frijs ML, Johansen B, Djurhuus JC, Gregersen H: Distension-induced duodenal contractions vary with the phases of the canine interdigestive migrating motility complex. Int. J. Surg. Invest. 1, 39-45 (1999)

81. Fujimiya M, Okumiya K, Yamane T, Maeda T: Distribution of serotonin immunoreactive nerve cells and fibers in the rat gastrointestinal tract. Histochem. Cell. Biol. 107, 105-114 (1997)

82. Fujino K, Inui A, Asakawa A, Kihara N, Fujimura M, Fujimiya M: Ghrelin induces fasted motor activity of the gastrointestinal tract in conscious fed rats. J. Physiol. (Lond.) 550, 227-240 (2003)

83. Funakoshi A, Glowniak J, Owyang C, Vinik AI: Evidence for cholinergic and vagal noncholinergic mechanisms modulating plasma motilin-like immunoreactivity. J. Clin. Endocrinol. Metab. 54, $1129-1134$ (1982) 
84. Furness JB, Costa M, Keast JR: Choline acetyltransferase and peptide immunoreactivity of submucous neurons in the small intestine of the guinea-pig. Cell Tissue Res. 237, 329-336 (1984)

85. Galligan JJ, Costa M, Furness JB: Gastrointestinal myoelectric activity in conscious guinea pigs. Am. J. Physiol. 249, G92-G99 (1985)

86. Gerner T: Pressure responses to OP-CCK compared to CCK-PZ in the antrum and fundus of isolated guinea pig stomachs. Scand. J. Gastroenterol. 14, 73-77 (1979)

87. Gershon MD: Review article: serotonin receptors and transporters - roles in normal and abnormal gastrointestinal motility. Aliment. Pharmacol. Ther. 20(Suppl. 7), 3-14 (2004)

88. Gilbert WR, Frank BH, Gavin JR, Gingerich RL: Characterization of specific pancreatic polypeptide receptors on basolateral membranes of canine small intestine. Proc. Natl. Acad. Sci. U S A 85, 4745-4749 (1988)

89. Gill RC, Pilot M-A, Thomas PA, Wingate DL: Organization of fasting and postprandial myoelectric activity in the stomach and duodenum of conscious dogs. Am. J. Physiol. 249, G655-G661 (1985)

90. Gleysteen JJ, Sarna SK, Myrvik AL: Canine cyclic motor activity of stomach and small bowel: the vagus is not the governor. Gastroenterology 88, 1926-1931 (1985)

91. Go VLW, Miller LJ: The role of gastrointestinal hormones in the control of postprandial and interdigestive gastrointestinal function. Scand. J. Gastroenterol. 18(Suppl. 82), 135-142 (1983)

92. Goedert M, Hunter JC, Ninkovic M: Evidence for neurotensin as a non-adrenergic, non-cholinergic neurotransmitter in guinea pig ileum. Nature 311, 59-62 (1984)

93. Gorard DA, Libby GW, Farthing MJ: 5-hydroxytryptamine and human small intestinal motility: effect of inhibiting 5-hydroxytryptamine uptake. Gut 35, 496-500 (1994)

94. Gray AC, White PJ, Coupar IM: Characterisation of opioid receptors involved in modulating circular and longitudinal muscle contraction in the rat ileum. Br. J. Pharmacol. 144, 687-694 (2004)

95. Greenberg GR: Role of vagal integrity in the regulation of postprandial somatostatin-28 and somatostatin-14 in dogs. Can. J. Physiol. Pharmacol. 64, 30 (1986)

96. Gregersen H, Rittig S, Vinter-Jensen L, Kraglund K: The relation between antral contractile activity and the duodenal component of the migrating motility complex. Scand. J. Gastroenterol. 23(Suppl. 152), 36-41 (1988)

97. Gregory PC, Miller SJ, Brewer AC: The relation between food intake and abomasal emptying and small intestinal transit time in sheep. Br. J. Nutr. 53, 373-380 (1985)

98. Grivel M-L, Ruckebusch Y: The propagation of segmental contractions along the small intestine. J. Physiol. (Lond.) 227, 611-625 (1972)

99. Grossman MI: Integration of neural and hormonal control of gastric secretion. Physiologist 6, $249-257$ (1963)

100. Grundy D: The intestinal mucosa as a target and trigger for enteric reflexes. Gut 47(Suppl. IV), iv44-iv45 (2000)

101. Gutierrez JG, Chey WY, Dinoso VP: Actions of cholecystokinin and secretin on the motor activity of the small intestine in man. Gastroenterology 67, 35-41 (1974)

102. Hall KE, Diamant NE, El-Sharkawy TY, Greenberg GR: Effect of pancreatic polypeptide on canine migrating motor complex and plasma motilin. Am. J. Physiol. 245, G178-G185 (1983)

103. Hall KE, Greenberg GR, El-Sharkawy TY, Diamant NE: Vagal control of migrating motor complex-related peaks in canine plasma motilin, pancreatic polypeptide, and gastrin. Can. J. Physiol. Pharmacol. 61, 1289-1298 (1982)

104. Hanauer SB: The role of loperamide in gastrointestinal disorders. Rev. Gastroenterol. Disord. 8, 15-20 (2008)

105. Hansen MB, Arif F, Gregersen H, Bruusgaard H, Wallin L: Effect of serotonin on small intestinal contractility in healthy volunteers. Physiol. Res. 57, 63-71 (2008)

106. Hasler WL (2006): Small intestinal motility. In: Physiology of the Gastrointestinal Tract, ed Johnson LR, Raven Press, New York, pp. 935-964

107. He Y, Wang H, Yang DY, Wang CY, Yang LL, Jin C: Differential expression of motilin receptor in various parts of gastrointestinal tract in dogs. Gastroenterol. Res. Pract. 2015, 970940 (2015)

108. Heel RC, Brogderi RN, Speight TM, Avery GS: Loperamide: a review of its pharmacological properties and therapeutic efficacy in diarrhea. Drugs 15, 33-52 (1978)

109. Heppell J, Becker JM, Kelly KA, Zinsmeister AR: Postprandial inhibition of canine enteric interdigestive myoelectric complex. Am. J. Physiol. 244, G160-G164 (1983)

110. Herzig KH, Schon I, Tatemoto K, Ohe Y, Li Y, Folsch UR, Owyang C: Diazepam binding inhibitor is a potent cholecystokinin-releasing peptide in the intestine. Proc. Natl. Acad. Sci. U S A 93, 7927-7932 (1996)

111. Himenos S, Tarui S, Kanayama S, Kuroshima T, Shinomura Y, Hayashi C, Tateishi K, Imagawa K, Hashimura E, Hamaoka T: Plasma cholecystokinin responses after ingestion of liquid meal and intraduodenal infusion of 
fat, amino acids, or hydrochloric acid in man: analysis with region specific radioimmunoassay. Am. J. Gastroenterol. 78, 703-707 (1983)

112. Hogan JP, Phillipson AT: The rate of flow of digesta and their removal among the digestive tract of the sheep. Br. J. Nutr. 14, 147-155 (1960)

113. Hoogerwerf WA: Role of the clock genes in gastrointestinal motility. Am. J. Physiol. 299, G549-G555 (2010)

114. Hostein J, Janssens J, Vantrappen G, Vandeweerd M, Leman G, Peeters TL: Somatostatin induces ectopic activity fronts (AF) of the migrating motor complex (MMC) via a local intestinal mechanism. Gastroenterology 87, 1004-1008 (1984)

115. Hökfelt T, Elfvin LG, Elde R, Schultzberg M, Goldstein M, Luft R: Occurrence of somatostatin-like immunoreactivity in some peripheral sympathetic noradrenergic neurons. Proc. Natl. Acad. Sci. U S A 74, 3587-3591 (1977)

116. Hoyer D, Clarke DE, Fozard JR, Hartig PR, Martin GR, Mylecharane EJ, Saxena PR, Humphrey PPA: VII. International Union of Pharmacology classification of receptors for 5-hydroxytryptamine (serotonin). Pharmacol. Rev. 46, 157-203 (1994)

117. Husebye E: The patterns of small bowel motility: physiology and implications in organic disease and functional disorders. Neurogastroenterol. Motil. 11, 141-161 (1999)

118. Inatomi N, Sato F, Marui S, Itoh Z, Omura S: Vagus-dependent and vagus-independent mechanisms of action of the erythromycin derivative EM574 and motilin in dogs. Jpn. J. Pharmacol. 71, 29-38 (1996)

119. Innis RB, Snyder SH: Distinct cholecystokinin receptors in brain and pancreas. Proc. Natl. Acad. Sci. U S A 77, 6917-6921 (1980)

120. Itoh Z: Motilin and clinical applications. Peptides 18, 593-608 (1997)

121. Itoh Z, Aizawa I, Takeuchi S, Honda R, Takahashi I, Mori K (1980): Mechanism by which the interdigestive motor pattern becomes irregular in conscious dogs. In: Gastrointestinal Motility, ed Christensen J, Raven Press, New York, pp. 279-286

122. Itoh Z, Honda R, Kiwatashi K, Takeuchi S, Aizawa I, Takayanagi R, Couch EF: Motilin-induced mechanical activity in the canine alimentary tract. Scand. J. Gastroenterol. 11(Suppl. 39), 93-110 (1976)

123. Itoh Z, Mizumoto A, Iwanaga Y, Yoshida N, Torii K, Wakabayashi K: Involvement of 5-hydroxytryptamine 3 receptors in regulation of interdigestive gastric contractions by motilin in the dog. Gastroenterology 100 , 901-908 (1991)

124. Itoh Z, Nakaya M, Suzuki T: Neurohormonal control of gastrointestinal motor activity in conscious dogs. Peptides 2(Suppl. 2), 223-228 (1981)

125. Itoh Z, Takeuchi S, Aizawa I, Takayanagi R: Effect of synthetic motilin on gastric motor activity in conscious dogs. Am. J. Dig. Dis. 22, 813-819 (1977)

126. Janssens J, Hellemans J, Adrian TE, Bloom SR, Peeters TL, Christofides N, Vantrappen GR: Pancreatic polypeptide is not involved in the regulation of the migrating motor complex in man. Regul. Pept. 3, 41-49 (1982)

127. Janssens J, Vantrappen G, Peeters TL, Hellemans J (1983): The activity front (AF) of the migrating motor complex (MMC) of the human stomach (but not of the small intestine) is motilin-dependent. In: Gastrointestinal Motility, eds Labo G, Bortolotti M, Cortina International, Verona, pp. 11-12

128. Johanson CE, Stopa EG, McMillan PN: The blood-cerebrospinal fluid barrier: structure and functional significance. Methods Mol. Biol. 686, 101-131 (2011)

129. Jonkers IJAM, Ledeboer M, Steens J, Smelt AHM, Masclee AAM: Effect of very long chain versus long chain triglycerides on gastrointestinal motility and hormone release in humans. Dig. Dis. Sci. 45, 1719-1726 (2000)

130. Katayama Y, Ooishi K, Hirai K, Homma T, Noda Y: Excitatory actions of motilin on myenteric neurons of the guinea-pig small intestine. Auton. Neurosci. 118, 88-92 (2005)

131. Kawamura O, Sekiguchi T, Kusano M, Nishioka T, Itoh Z: Effect of erythromycin on interdigestive gastrointestinal contractile activity and plasma motilin concentration in humans. Dig. Dis. Sci. 38, 870-876 (1983)

132. Keast JR, Furness JB, Costa M: Somatostatin in human enteric nerves. Distribution and characterization. Cell Tissue Res. 237, 299-308 (1984)

133. Keinke O, Wulschke S, Ehrlein HJ: Neurotensin slows gastric emptying by a transient inhibition of gastric and prolonged inhibition of duodenal motility. Digestion 34, 281-288 (1986)

134. Kellum JM, Maxwell RJ, Potter J, Kummerle JF: Motilin's induction of phasic contractility in canine jejunum is mediated by the luminal release of serotonin. Surgery 100, 445-451 (1986)

135. Kelly KA (1975): The effect of pentagastrin on canine gastric myoelectric and motor activity. In: Gastrointestinal Hormones, ed Thompson JC, Austin University of Texas Press, Austin, TX, pp. 381-389 
136. Kerlin P, Phillips SF: Variability of motility of the ileum and jejunum in healthy humans. Gastroenterology 82 , 694-700 (1982)

137. Kim D-Y, Camilleri M: Serotonin: a mediator of the brain-gut connection. Am. J. Gastroenterol. 95, 2698-2709 (2000)

138. Kobayashi RM, Brown M, Vale W: Regional distribution of neurotensin and somatostatin in rat brain. Brain Res. 126, 584-588 (1977)

139. Kojima M, Hosoda H, Date Y, Nakazato M, Matsuo H, Kangawa K: Ghrelin is a growth hormone-releasing acylated peptide from stomach. Nature 402, 656-660 (1999)

140. Konturek SJ, Radecki T, Thor P, Dembiński A: Release of cholecystokinin by amino acids. Proc. Soc. Exp. Biol. Med. 143, 305-309 (1973)

141. Kumar D, Wingate D, Ruckebusch Y: Circadian variation in the propagation velocity of the migrating motor complex. Gastroenterology 91, 926-930 (1986)

142. Lang IM, Sarna SK: All intense bursts of rhythmic activity may not be phase III activity. Am. J. Physiol. 252, G592-G593 (1987)

143. Larsson L-L, Goltermann N, de Magistris L, Rehfeld JF, Schwartz TW: Somatostatin cell processes as pathways for paracrine secretion. Science 205, 1393-1395 (1979)

144. Larsson L-L, Rehfeld JF: Distribution of gastrin and CCK cells in the rat gastrointestinal tract. Histochemistry 58, 23-31 (1978)

145. Larsson L-L, Rehfeld JF: Localization and molecular heterogeneity of cholecystokinin in the central and peripheral nervous system. Brain Res. 165, 201-218 (1979)

146. Ledeboer M, Masclee AA, Coenraad M, Vecht J, Biemond I, Lamers CB: Antroduodenal motility and small bowel transit during continuous intraduodenal or intragastric administration of enteral nutrition. Eur. J. Clin. Invest. 29, 615-623 (1999)

147. Lee KY, Chang TM, Chey WY: Effect of electrical stimulation of the vagus on plasma motilin concentration in dog. Life Sci. 29, 1093-1097 (1981)

148. Lee KY, Chang TM, Chey WY: Effect of rabbit antimotilin serum on myoelectric activity and plasma motilin concentration in fasting dog. Am. J. Physiol. 245, G547-G553 (1983)

149. Lee KY, Chey WY, Tai H, Yajima H: Radioimmunoassay of motilin: validation and studies on the relationship between plasma motilin and interdigestive myoelectric activity of the duodenum of dog. Dig. Dis. 23, 789-795 (1978)

150. Lee KY, Park KJ, Chang TM, Chey WY: Cholinergic role on release and action of motilin. Peptides 4, 375-380 (1983)

151. Lemoyne M, Wassef R, Tasse D, Trudel L, Poitras P: Motilin and the vagus in dogs. Can. J. Physiol. Pharmacol. 62, 1092-1096 (1984)

152. Lentle RG, Janssen PWM (2011): The Physical Process of Digestion. Springer Science, New York

153. Lester GD, Bolton JR: Effect of dietary composition on abomasal and duodenal myoelectrical activity. Res. Vet. Sci. 57, 270-276 (1994)

154. Levant JA, Kun TL, Jachna J, Sturdevant RAL, Isenberg JI: The effects of graded doses of C-terminal octapeptide of cholecystokinin on small intestinal transit time in man. Dig. Dis. Sci. 19, 207-209 (1974)

155. Lewis TD, Collins SM, Fox J-AE, Daniel EE: Initiation of duodenal acid-induced motor complexes. Gastroenterology 77, 1217-1224 (1979)

156. Liddle RA: Cholecystokinin cells. Annu. Rev. Physiol. 59, 221-242 (1997)

157. Liddle RA, Goldfine ID, Rosen MS, Taplitz RA, Williams JA: Cholecystokinin bioactivity in human plasma: molecular forms, responses to feeding, and relationship to gallbladder contraction. J. Clin. Invest. 75, 1144-1152 (1985)

158. Lin S, Shi YC, Yulyaningsih E, Aljanova A, Zhang L, Macia L, Nguyen AD, Lin EJ, During MJ, Herzog H, Sainsbury A: Critical role of arcuate Y4 receptors and the melanocortin system in pancreatic polypeptideinduced reduction in food intake in mice. PLoS One 4, e8488 (2009)

159. Lin TM, Chance RE (1978): Spectrum of gastrointestinal actions of bovine PP. In: Gut Hormones, ed Bloom SR, Churchill Livingstone, London, pp. 242-246

160. Lingenfelser T, Sun W-M, Hebbard GS, Dent J, Horowitz M: Effect of duodenal distension on antropyloroduodenal pressures and perception are modified by hyperglycemia. Am. J. Physiol. 276, G711-G718 (1999)

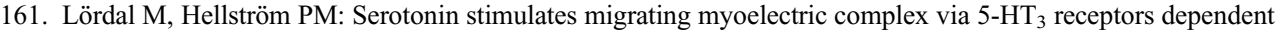
on cholinergic pathways in rat small intestine. Neurogastroenterol. Motil. 11, 1-10 (1999)

162. Lux G, Femppel J, Lederer P, Rösch W, Domschke W: Increased duodenal alkali load associated with the interdigestive migrating myoelectric complex. Acta Hepato-Gastroenterol. 26, 166-169 (1979) 
163. Marik F, Code CF: Control of the interdigestive myoelectric activity in dogs by the vagus nerves and pentagastrin. Gastroenterology 69, 387-395 (1975)

164. McTigue DM, Rogers RC: Pancreatic polypeptide stimulates gastric motility through a vagal-dependent mechanism in rats. Neurosci. Lett. 188, 93-96 (1995)

165. Medhus AW, Sandstad O, Bredesen J, Husebye E: Stimulation of the small intestine by nutrients in relation to phase of the migrating motor complex. Scand. J. Gastroenterol. 35, 494-500 (2000)

166. Merle A, Delagrange P, Renard P, Lesieur D, Cuber JC, Roche M, Pellisier S: Effect of melatonin on motility pattern of the small intestine in rats and its inhibition by melatonin receptor antagonist S 22153. J. Pineal Res. 29, 116-124 (2000)

167. Meyer JH, Jones RS: Canine pancreatic responses to intestinally perfused fat and products of fat digestion. Am. J. Physiol. 226, 1178-1187 (1974)

168. Michel MC, Beck-Sickinger A, Cox H, Doods HN, Herzog H, Larkammar D, Quirion R, Schwartz T, Westfall T: XVI. International Union of Pharmacology recommendations for the nomenclature of neuropeptide Y, peptide YY, and pancreatic polypeptide receptors. Pharmacol. Rev. 50, 143-150 (1998)

169. Miller RJ, Hirning LD (1989): Opioid peptides in the gut. In: Handbook of Physiology. The Gastrointestinal System, ed Schultz SG, American Physiological Society, Bethesda, MD, pp. 631-660

170. Miller P, Roy A, St-Pierre S, Dagenais M, Lapointe R, Poitras P: Motilin receptors in the human antrum. Am. J. Physiol. 278, G18-G23 (2000)

171. Miolan JP, Roman C: Discharge of efferent vagal fibers supplying gastric antrum: indirect study by nerve suture technique. Am. J. Physiol. 235, E366-E373 (1978)

172. Mitznegg P, Bloom SR, Domschke W, Haecki WH, Domschke S, Belohlavek D, Wünsch E, Demling L: Effect of secretin on plasma motilin in man. Gut 18, 468-477 (1977)

173. Miyano Y, Sakata I, Kuroda K, Aizawa S, Tanaka T, Jogahara T, Kurotani R, Sakai T: The role of the vagus nerve in the migrating motor complex and ghrelin- and motilin-induced gastric contraction in suncus. PLoS One 8, e64777 (2013)

174. Mochiki E, Satoh M, Tamura T, Haga N, Suzuki H, Mizumoto A, Sakai T, Itoh Z: Endogenous motilin stimulates endogenous release of motilin through cholinergic muscarinic pathways in the dog. Gastroenterology 111, 1456-1464 (1996)

175. Moller LN, Stidsen CF, Hartmann B, Holst JJ: Somatostatin receptors. Biochim. Biophys. Acta 1616, 1-84 (2003)

176. Mondal A, Xie Z, Miyano Y, Tsutsui C, Sakata I, Kawamoto Y, Aizawa S, Tanaka T, Oda S-I, Sakai T: Coordination of motilin and ghrelin regulates the migrating motor complex of gastrointestinal motility in Suncus murinus. Am. J. Physiol. 302, G1207-G1215 (2012)

177. Morgan KG, Schmalz PF, Go VL, Szurszewski JH: Effects of pentagastrin, G17, and G34 on the electrical and mechanical activities of canine antral smooth muscle. Gastroenterology 75, 405-412 (1978)

178. Mosińska P, Zielińska M, Fichna J: Expression and physiology of opioid receptors in the gastrointestinal tract. Curr. Opin. Endocrinol. Diabet. Obes. 23, 3-10 (2016)

179. Mukopadhyay A, Thor P, Copeland E, Johnson L, Weisbrodt N: Effect of cholecystokinin on myoelectric activity of small bowel of the dog. Am. J. Physiol. 232, E44-E47 (1977)

180. Nakajima H, Mochiki E, Zietlow A, Ludwig K, Takahashi T: Mechanism of interdigestive migrating motor complex in conscious dogs. J. Gastroenterol. 45, 506-514 (2010)

181. Neunlist M, Schemann M: Nutrient-induced changes in the phenotype and function of the enteric nervous system. J. Physiol. (Lond.) 592, 2959-2965 (2014)

182. Niebel W, Eysselein VE, Singer MV: Pancreatic polypeptide response to a meal before and after cutting the extrinsic nerves of the upper gastrointestinal tract and the pancreas in the dog. Dig. Dis. Sci. 32, 1004-1009 (1987)

183. Noble F, Wank SA, Crawley JN, Bradwejn J, Seroogy KB, Hamon M, Roques BP: International Union of Pharmacology. XXI. Structure, distribution, and functions of cholecystokinin receptors. Pharmacol. Rev. 51, 745-781 (1999)

184. Ooms LA, Degryse AD, Janssen PA: Mechanisms of action of loperamide. Scand. J. Gastroenterol. 96, 145-155 (1984)

185. Ormsbee HS, Koehler SL, Telford GL: Somatostatin inhibits motilin-induced interdigestive contractile activity in the dog. Dig. Dis. Sci. 23, 781-788 (1978)

186. Ormsbee III HS, Telford GL, Mason GR: Required neural involvement in control of canine migrating motor complex. Am. J. Physiol. 237, E451-E456 (1979)

187. Ormsbee III HS, Telford LG, Suter GM, Wilson PD, Mason GR: Mechanism of propagation of canine migrating motor complex - a reappraisal. Am. J. Physiol. 240, G141-G146 (1981) 
188. Ouyang A, Sunshine AG, Reynolds JC: Caloric content of a meal affects duration but not contractile pattern of duodenal motility in man. Dig. Dis. Sci. 34, 528-536 (1989)

189. Peeters TL: Central and peripheral mechanisms by which ghrelin regulates gut motility. J. Physiol. Pharmacol. 54(Suppl. 4), 95-103 (2003)

190. Peeters TL: Ghrelin and the gut. Endocr. Dev. 25, 41-48 (2013)

191. Penman E, Wass JA, Butler MG, Penny ES, Price J, Wu P, Rees LH: Distribution and characterisation of immunoreactive somatostatin in human gastrointestinal tract. Regul. Pept. 7, 53-65 (1983)

192. Pilot M-A, Thompson HH, Zara GP: Mechanism of action of 5-hydroxytryptamine on canine intestinal motility. J. Physiol. (Lond.) 354, 41P (1984)

193. Piñeiro-Carrero VM, Clench MH, Davis RH, Andres JM, Franzini DA, Mathias JR: Intestinal motility in rats after serotonergic neuron destruction. Am. J. Physiol. 260, G232-G239 (1991)

194. Poitras P: Motilin is a digestive hormone in the dog. Gastroenterology 87, 909-913 (1984)

195. Poitras P, Steinbach JH, Van Deventer G, Code CF, Walsh JH: Motilin-independent ectopic fronts of the interdigestive myoelectric complex in dogs. Am. J. Physiol. 239, G215-G220 (1980)

196. Polak JM, Pearse AGE, Grimelius L, Bloom SR, Arimura A: Growth-hormone release-inhibiting hormone in gastrointestinal and pancreatic D cells. Lancet 1, 1220-1224 (1975)

197. Polak JM, Pearse AGE, Heath CM: Complete identification of endocrine cells in the gastrointestinal tract using semithin-thin sections to identify motilin cells in human and animal intestine. Gut 16, 224-229 (1975)

198. Polak JM, Sullivan SN, Bloom SR: Specific localisation of neurotensin to the $\mathrm{N}$ cell in human intestine by radioimmunoassay and immunocytochemistry. Nature 270, 183-184 (1977)

199. Pouderoux P, Veyrac M, Michel H: Sham feeding disrupts phase III of the duodenal migrating motor complex in humans. Neurogastroenterol. Motil. 7, 139-144 (1995)

200. Quigley EM: Cisapride: what can we learn from the rise and fall of a prokinetic? J. Dig. Dis. 12, 147-156 (2011)

201. Raybould HE: Visceral perception: sensory transduction in visceral afferents and nutrients. Gut 51(Suppl. 1), 11-14 (2002)

202. Raybould HE, Taché Y: Cholecystokinin inhibits gastric motility and emptying via a capsaicin-sensitive vagal pathway in rats. Am. J. Physiol. 255, G242-G246 (1988)

203. Redfern JS, Thirlby R, Feldman M, Richardson CT: Effect of pentagastrin on gastric mucosal histamine in dogs. Am. J. Physiol. 248, G369-G375 (1985)

204. Rehfeld JF: Immunochemical studies on cholecystokinin. II. Distribution and molecular heterogeneity in the central nervous system and small intestine of man and hog. J. Biol. Chem. 253, 4022-4030 (1978)

205. Riachi G, Ducrotte P, Guedon C, Bouteloup C, Denis P, Colin R, Lerebours E: Duodenojejunal motility after oral and enteral nutrition in humans: a comparative study. J. Parenter. Enteral Nutr. 20, 150-155 (1996)

206. Rivière PJ, Liberge M, Murillo-Lopez D, Bueno L: Opposite central and peripheral control by endogenous opioids of intestinal motility in fed rats. Br. J. Pharmacol. 98, 236-242 (1989)

207. Robinson R, Gershon MD: Synthesis and uptake of 5-hydroxytryptamine by the myenteric plexus of the small intestine of the guinea pig. J. Pharmacol. Exp. Ther. 179, 29-41 (1971)

208. Rodriguez-Membrilla A, Vergara P: Endogenous CCK disrupts the MMC pattern via capsaicin-sensitive vagal afferent fibers in the rat. Am. J. Physiol. 272, G100-G105 (1997)

209. Rökaeus A, Burcher E, Chang D, Folkers K, Rossell S: Actions of neurotensin and (Gln-4)-neurotensin on isolated tissues. Acta Pharmacol. Toxicol. (Copenh.) 41, 141-147 (1977)

210. Roman C, Gonella J (1987): Extrinsic control of digestive tract motility. In: Physiology of the Gastrointestinal Tract, ed Johnson LR, Raven Press, New York, pp. 507-553

211. Romański KW: The rebound excitation triggered by anticholinergic drugs from ovine pyloric antrum, small bowel and gallbladder. J. Physiol. Pharmacol. 54, 121-133 (2003)

212. Romański KW: The effect of cholecystokinin octapeptide upon the migrating myoelectric complex in the ovine small bowel. Acta Vet. 57, 113-122 (2007)

213. Romański KW: Migrating motor complex in biological sciences: characterization, animal models and disturbances. Indian J. Exp. Biol. 47, 229-244 (2009)

214. Romański KW: Analysis of the excitatory motor response evoked by nicotinic and muscarinic blockade of ovine small bowel. Pharmacol. Rep. 62, 292-303 (2010)

215. Romański KW, Goździewska K: Specific effect of pirenzepine on myoelectric and motor activity in ovine small bowel. Revue Méd. Vét. 161, 401-408 (2010)

216. Rossell S, Al-Saffar A, Thor K: The role of neurotensin in gut motility. Scand. J. Gastroenterol. 19(Suppl. 96), 69-75 (1984) 
217. Ruckebusch Y (1989): Gastrointestinal motor functions in ruminants. In: Handbook of Physiology - The Gastrointestinal System I, ed Schultz SG, American Physiological Society, Bethesda, MD, pp. 1225-1282

218. Ruckebusch Y, Buéno L: The effect of feeding on the motility of the stomach and small intestine of the pig. Br. J. Nutr. 35, 397-405 (1976)

219. Ruckebusch Y, Malbert CH, Crichlow EC: Hexamethonium: a probe to assess autonomic nervous system involvement in upper gastrointestinal functions in conscious sheep. Vet. Res. Commun. 11, 293-303 (1987)

220. Saffouri B, Duval JW, Makhlouf M: Stimulation of gastrin secretion in vitro by intraluminal chemicals: regulation by intramural cholinergic and noncholinergic neurons. Gastroenterology 87, 557-561 (1984)

221. Sakai Y, Daniel EE, Jury J, Fox JET: Neurotensin inhibition of canine intestinal motility in vivo via $\alpha-$ adrenoceptors. Can. J. Physiol. Pharmacol. 62, 403-411 (1984)

222. Sanger GJ, Wang Y, Hobson A, Broad J: Motilin: towards a new understanding of the gastrointestinal neuropharmacology and therapeutic use of motilin receptor agonists. Br. J. Pharmacol. 170, 1323-1332 (2013)

223. Sarna SK: Cyclic motor activity; migrating motor complex: 1985. Gastroenterology 89, 894-913 (1985)

224. Sarna SK (2002): Myoelectrical and contractile activities of the gastrointestinal tract. In: Schuster Atlas of Gastrointestinal Motility, eds Schuster MM, Crowell MD, Koch KL, B. C. Decker, Hamilton, pp. 1-18

225. Sarna S, Chey WY, Condon RE, Dodds WJ, Myers T, Chang TM: Cause-and-effect relationship between motilin and migrating myoelectric complexes. Am. J. Physiol. 245, G277-G284 (1983)

226. Sarna SK, Condon RE, Cowles V: The enteric mechanisms of initiation of migrating motor complexes (MMCs) in dogs. Gastroenterology 84, 814-822 (1983)

227. Sarna SK, Lang IM, Gleysteen JJ, Otterson MF (1989): Central vs. enteric neural control of small intestinal migrating motor complexes. In: Nerves and the Gastrointestinal Tract, eds Singer MV, Goebell H, MTP Press Ltd., Lancaster, pp. 746-752

228. Sarna S, Northcott P, Belbeck L: Mechanism of cycling of migrating myoelectric complexes: effect of morphine. Am. J. Physiol. 242, G588-G595 (1982)

229. Sarna SK, Otterson MF: Small intestinal amyogenesia and dysmyogenesia induced by morphine and loperamide. Am. J. Physiol. 258, G282-G289 (1990)

230. Sarna SK, Stoddard C, Belbeck L, McWade D: Intrinsic nervous control of migrating myoelectric complexes (MMC's). Am. J. Physiol. 241, G16-G23 (1981)

231. Sarr MG, Spencer MP, Hakim NS, Van Lier Ribbink JA, Duenes JA, Zinsmeister AR (1989): Control of interdigestive motility patterns of the stomach and jejunum: neural vs. hormonal. In: Nerves and the Gastrointestinal Tract, eds Singer MV, Goebell H, Kluwer Academic Publishers, Dordrecht, pp. 399-415

232. Sarret P, Krzywkowski P, Segal L, Nielsen MS, Petersen CM, Mazella J, Stroh T, Beaudet A: Distribution of NTS3 receptor/sortilin mRNA and protein in the rat central nervous system. J. Comp. Neurol. 461, 483-505 (2003)

233. Schang JC, Dauchel J, Sava P, Angel F, Bouchet P, Lambert A, Grenier JF: Specific effects of different food components on intestinal motility. Eur. Surg. Res. 10, 425-432 (1978)

234. Schang JC, Kelly KA: Inhibition of canine interdigestive proximal gastric motility by cholecystokinin octapeptide. Am. J. Physiol. 240, G217-G220 (1981)

235. Schemann M, Ehrlein H-J: Mechanical characteristics of phase II and phase III of the interdigestive migrating motor complex in dogs. Gastroenterology 91, 117-123 (1986)

236. Schemann M, Neunlist M: The human enteric nervous system. Neurogastroenterol. Motil. 16(Suppl. 1), 55-59 (2004)

237. Schemann M, Tamura K: Presynaptic inhibitory effects of the peptides NPY, PYY, and PP on nicotinic EPSPs in guinea-pig gastric myenteric neurons. J. Physiol. (Lond.) 451, 79-89 (1992)

238. Scheurer U, Varga L, Drack E, Burki H-R, Halter F: Mechanism of action of cholecystokinin octapeptide on rat antrum, pylorus, and duodenum. Am. J. Physiol. 244, G266-G272 (1983)

239. Schippers E, Janssens J, Vantrappen G, Vandeweerd M, Peeters TL: Somatostatin induces ectopic activity fronts via a local intestinal mechanism during fed state or pentagastrin. Am. J. Physiol. 250, G149-G154 (1986)

240. Schmidt PT, Degerblad M, Lindström E, Sunqvist M, Naslund E, Gilberg PG, Husebye E, Theodorsson E, Hellström PM: Circulating ghrelin levels after food intake during different phases of the migrating motor complex in man. Eur. J. Clin. Invest. 36, 503-508 (2006)

241. Schmidt PT, Näslund E, O'Shaughnessy C, Hellström PM: The pancreatic polypeptide family and the migrating motor complex of the rat: differential effects in the duodenum and jejunum. Regul. Pept. 139, 59-64 (2007) 
242. Schönfeld JV, Evans DF, Renzing K, Castillo FD, Wingate DL: Human small bowel motor activity in response to liquid meals of different caloric value and different chemical composition. Dig. Dis. Sci. 43, 265-269 (1998)

243. Schönfeld J, Evans DF, Wingate DL: Daytime and night time motor activity of the small bowel after solid meals of different caloric value in humans. Gut 40, 614-618 (1997)

244. Schubert ML, Coy DH, Makhlouf GM: Peptone stimulates gastrin secretion from the stomach by activating bombesin/GRP and cholinergic neurons. Am. J. Physiol. 262, G685-G689 (1992)

245. Schubert ML, Jong ML, Makhlouf GM: Bombesin/GRP-stimulated somatostatin secretion is mediated by gastrin in the antrum and intrinsic neurons in the fundus. Am. J. Physiol. 261, G885-G889 (1991)

246. Schultzberg M, Hökfelt T, Nilsson G, Terenius L, Rehfeld JF, Brown M, Elde R, Goldstein M, Said S: Distribution of peptide- and catecholamine-containing neurons in the gastro-intestinal tract of rat and guinea pig: immunohistochemical studies with antisera to substance $P$, vasoactive intestinal polypeptide, enkephalins, somatostatin, gastrin/cholecystokinin, neurotensin and dopamine- $\beta$-hydroxylase. Neuroscience 5, 689-744 (1980)

247. Schwartz GJ, McHugh PR, Moran TH: Gastric loads and cholecystokinin synergistically stimulate rat gastric vagal afferents. Am. J. Physiol. 265, R872-R876 (1993)

248. Schwartz RW: Panceratic polypeptide: a unique model for vagal control of endocrine systems. J. Auton. Nerv. Syst. 9, 99-113 (1983)

249. Schwartz TW, Stenquist B, Olbe L: Cephalic phase of pancreatic polypeptide secretion studied by sham feeding in man. Scand. J. Gastroenterol. 14, 313-320 (1979)

250. Seybold VS, Treder BG, Aanonsen LM, Parsons A, Brown DR: Neurotensin binding sites in porcine jejunum: biochemical characterization and intramural localization. Synapse 6, 81-90 (1990)

251. Siadati MR, Murr MM, Foley MK, Duenes JA, Steers JL, Sarr MG: In situ neural isolation of the entire canine upper gut: effects of fasting and fed motility patterns. Surgery 121, 174-181 (1997)

252. Siegle M-L, Ehrlein H-J: Neurotensin changes the motor pattern in canine ileum from propulsive to segmenting. Dig. Dis. Sci. 34, 1521-1527 (1989)

253. Smith AN, Hogg D: Effect of gastrin II on the motility of the gastrointestinal tract. Lancet 1, 403 (1966)

254. Smith D, Waldron B, Campbell FC: Response of migrating motor complex to variation of fasting intraluminal content. Am. J. Physiol. 263, G533-G537 (1992)

255. Soffer EE, Adrian TE: Effect of meal composition and sham feeding on duodenojejunal motility in humans. Dig. Dis. Sci. 37, 1009-1014 (1992)

256. Spannagel AW, Green GM, Guan D, Liddle RA, Faull K, Reeve JR Jr: Purification and characterization of a luminal cholecystokinin-releasing factor from rat intestinal secretion. Proc. Natl. Acad. Sci. U S A 93, 4415-4420 (1996)

257. Steigerwalt RW, Williams JA: Binding specificity of the mouse cerebral cortex receptor for small cholecystokinin peptides. Regul. Pept. 8, 51-59 (1984)

258. Stewart JJ: Actions of cholecystokinin octapeptide on smooth muscle of isolated dog intestine. Am. J. Physiol. 232, E306-E310 (1977)

259. Summers RW, Anuras S, Green J: Jejunal manometry patterns in health, partial intestinal obstruction, and pseudoobstruction. Gastroenterology 85, 1290-1300 (1983)

260. Summers RW, Flatt A, Yanda RJ, Yamada T: Isoproterenol induces activity fronts in fed dogs through somatostatin release. Gastroenterology 87, 999-1003 (1984)

261. Szurszewski J: Mechanism of action of pentagastrin and acetylcholine on the longitudinal muscle of canine antrum. J. Physiol. (Lond.) 252, 335-361 (1975)

262. Szurszewski JH: A migrating electric complex of the canine small intestine. Am. J. Physiol. 217, 1757-1763 (1969)

263. Tack J: Georges Brohee Prize 1994. Motilin and the enteric nervous system in the control of interdigestive and postprandial motility. Acta Gastroenterol. Belg. 58, 21-30 (1995)

264. Tack J, Depoortere I, Bisschops R, Delporte C, Meulemans A, Janssens J, Peeters T: Influence of ghrelin on interdigestive gastrointestinal motility in humans. Gut 55, 327-333 (2006)

265. Takahashi T: Interdigestive migrating motor complex - its mechanism and clinical importance. J. Smooth Muscle Res. 49, 99-111 (2013)

266. Takeda M, Mizutani Y, Yamano M, Tsukamoto K, Suzuki T: Gastric emptying in diabetic gastroparetic dogs: effects of SK-951, a novel prokinetic agent. Pharmacology 62, 23-28 (2001)

267. Takeshita E, Matsuura B, Dong M, Miller LJ, Matsui H, Onji M: Molecular characterization and distribution of motilin family receptors in the human gastrointestinal tract. J. Gastroenterol. 41, 223-230 (2006)

268. Tanaka T, Kendrick ML, Zyromski NJ, Meile T, Sarr MG: Vagal innervation modulates motor pattern but not initiation of canine migrating motor complex. Am. J. Physiol. 281, G283-G292 (2001) 
269. Tanaka T, Mizumoto A, Mochiki E, Haga N, Suzuki H, Itoh Z: Relationship between intraduodenal 5-hydroxytryptamine release and interdigestive contractions in dogs. J. Smooth Muscle Res. 40, 75-84 (2004)

270. Tanaka M, Sarr MG: Total duodenectomy: effect on canine gastrointestinal motility. J. Surg. Res. 42, 483-493 (1987)

271. Tanaka M, Sarr MG: Role of the duodenum in the control of canine gastrointestinal motility. Gastroenterology 94, 622-629 (1988)

272. Tanaka T, Van Klompenberg LH, Sarr MG: Selective role of vagal and nonvagal innervation in initiation and coordination of gastric and small bowel patterns of interdigestive and postprandial motility. J. Gastrointest. Surg. 5, 418-433 (2001)

273. Taniyama K, Makimoto N, Furuichi A, Sakurai-Yamashita Y, Nagase Y, Kaibara M, Kanematsu T: Functions of peripheral 5-hydroxytryptamine receptors, especially 5-hydroxytryptamine 4 receptor, in gastrointestinal motility. J. Gastroenterol. 35, 575-582 (2000)

274. Taylor IL, Feldman M, Richardson CT, Walsh JH: Gastric and cephalic stimulation of human pancreatic polypeptide release. Gastroenterology 75, 432-437 (1978)

275. Tepperman BL, Walsh JH, Preshaw RM: Effect of antral denervation on gastrin release by sham feeding and insulin hypoglycemia in dogs. Gastroenterology 63, 973-980 (1972)

276. Thomas TJ, Pauze D, Love JN: Are one or two dangerous? Diphenoxylate-atropine exposure in toddlers. J. Emerg. Med. 34, 71-75 (2008)

277. Thomson ABR, Drozdowski L, Iordache C, Thomson BKA, Vermeire S, Clandinin MT, Wild G: Small bowel review: normal physiology part 2. Dig. Dis. Sci. 48, 1565-1581 (2003)

278. Thor K, Rosell S, Rökaeus $\AA$, Kager L: (Gln4)-neurotensin changes the motility pattern of the duodenum and proximal jejunum from a fasting-type to a fed-type. Gastroenterology 83, 569-574 (1982)

279. Thor PJ, Konturek JW, Konturek SJ: Pancreatic polypeptide and intestinal motility in dogs. Dig. Dis. Sci. 32, 513-519 (1987)

280. Thor PJ, Konturek JW, Sendur R, Konturek SJ (1984): Comparison of neurotensin and fat on myoelectric activity pattern of the small bowel. In: Gastrointestinal Motility, ed Roman C, MTP Press Ltd., Lancaster, pp. 343-348

281. Thor PJ, Krolczyk H, Gil K, Żurowski D, Nowak L: Melatonin and serotonin effects on gastrointestinal motility. J. Physiol. Pharmacol. 58(Suppl. 6), 97-103 (2007)

282. Thor P, Król R, Konturek SJ, Coy DH, Schally AV: Effect of somatostatin on myoelectrical activity of small bowel. Am. J. Physiol. 235, E249-E254 (1978)

283. Tohara K, Uchida Y, Suzuki H, Itoh Z: Initiation of phase III contractions in the jejunum by atropine, hexamethonium and xylocaine in conscious dogs. Neurogastroenterol. Motil. 12, 11-21 (2000)

284. Tomasetto C, Karam SM, Ribieras S, Masson R, Levebvre O, Staub A, Alexander G, Chenard MP, Rio MC: Identification and characterization of a novel gastric peptide hormone: the motilin-related peptide. Gastroenterology 119, 395-405 (2000)

285. Tomita R: Relationship between interdigestive migrating motor complex and gut hormones in human. Hepatogastroenterology 56, 714-717 (2009)

286. Tonini M, Pace F: Drugs acting on serotonin receptors for the treatment of functional GI disorders. Dig. Dis. 24 , 59-69 (2006)

287. Uvnäs-Wallensten K, Efendic S, Luft R: The occurrence of somatostatin-like immunoreactivity in the vagal nerves. Acta Physiol. Scand. 102, 248-250 (1978)

288. Uvnäs-Wallenstein K, Rehfeld JF, Larson LI, Uvnas B: Heptadecapeptide gastrin in the vagal nerve. Proc. Natl. Acad. Sci. U S A 74, 5707-5710 (1977)

289. Vandeweerd M, Janssens J, Vantrappen G, Schippers E, Hostein J, Peeters TL: Local nerve blockade by tetrodotoxin induces ectopic phase 3 of the migrating myoelectric complex in dogs. Scand. J. Gastroenterol. 23, 47-52 (1988)

290. Vantrappen G, Janssens J, Hellemans J, Ghoos Y: The interdigestive motor complex of normal subjects and patients with bacterial overgrowth of the small intestine. J. Clin. Invest. 59, 1158-1166 (1977)

291. Vantrappen G, Janssens J, Peeters TL, Bloom SR, Christofides ND, Hellemans J: Motilin and the interdigestive migrating motor complex in man. Dig. Dis. Sci. 24, 497-500 (1979)

292. Verkijk M, Vecht J, Gielkens HA, Lamers CB, Masclee AA: Effects of medium-chain and long-chain triglycerides on antroduodenal motility and small bowel transit time in man. Dig. Dis. Sci. 42, 1933-1939 (1997)

293. Vincent JP, Mazella J, Kitabgi P: Neurotensin and neurotensin receptors. Trends Pharmacol. Sci. 20, 302-309 (1999) 
294. Vinik AI, Gaginella TS, O’Dorisio TM, Shapiro B, Wagner L: The distribution and characterization of somatostatin-like immunoreactivity in epithelial cells, submucosa, and muscle of the rat stomach and intestine. Endocrinology 109, 1921-1926 (1981)

295. Vizi ES, Bertaccini G, Impicciatore M, Mantovani P, Zseli J, Knoll J: Structure-activity relationship of some analogues of gastrin and cholecystokinin on intestinal smooth muscle of the guinea pig. Naunyn-Schmiedebergs Arch. Pharmacol. 284, 233-243 (1974)

296. Vizi ES, Ono K, Adam-Vizi V, Duncalf D, Földes FF: Presynaptic inhibitory effect of Met-enkephalin on [14C] acetylcholine release from the myenteric plexus and its interaction with muscarinic negative feedback inhibition. J. Pharmacol. Exp. Ther. 230, 493-499 (1984)

297. Walker JP, Fujimura M, Sakamoto T, Greeley GH Jr, Townsend CM Jr, Thompson JC: Importance of the ileum in neurotensin released by fat. Surgery 98, 224-229 (1985)

298. Walsh JH (1994): Gastrointestinal hormones. In: Physiology of the Gastrointestinal Tract, ed Johnson LR, Raven Press, New York, pp. 1-128

299. Walsh J, Grossman M: Medical progress: gastrin. N. Engl. J. Med. 292, 1324-1332 (1975)

300. Wang Y, Dong L, Cheng Y, Zhao P: Effects of ghrelin on feeding regulation and interdigestive migrating complex in rats. Scand. J. Gastroenterol. 42, 447-453 (2007)

301. Watanabe A, Mochiki E, Kimura A, Kogure N, Yanai M, Ogawa A, Toyomasu Y, Ogata K, Ohno T, Suzuki H, Kuwano H: Nesfatin-1 suppresses gastric contractions and inhibits interdigestive migrating contractions in conscious dogs. Dig. Dis. Sci. 60, 1595-1602 (2015)

302. Weisbrodt NW (1981): Motility of the small intestine. In: Physiology of the Gastrointestinal Tract, ed Johnson LR, Raven Press, New York, pp. 411-443

303. Weisbrodt NW (1984): Basic control mechanisms. In: Gastric and Gastrointestinal Motility, eds Akkermans LMA, Johnson AG, Read NW, Praeger, New York, pp. 3-20

304. Weisbrodt NW, Copeland EM, Kearley RW, Moore EP, Johnson LR: Effects of pentagastrin on electrical activity of small intestine of the dog. Am. J. Physiol. 227, 425-429 (1974)

305. Weisbrodt NW, Copeland EM, Thor PJ, Mukhopadhyay AK, Johnson LR (1975): Nervous and humoral factors which influence the fasted and fed patterns of intestinal myoelectric activity. In: Proceedings of the Fifth International Symposium on Gastrointestinal Motility, ed Vantrappen G, Typoff Press, Herentals, pp. 82-87

306. Werther GA, Sperling MA, Joffe S, Murphy RF: The regulation of basal pancreatic polypeptide levels in dogs. Regul. Pept. 17, 191-198 (1987)

307. Whitcomb DC, Puccio AM, Vigna SR, Taylor IL, Hoffman GE: Distribution of pancreatic polypeptide receptors in the rat brain. Brain Res. 760, 137-149 (1997)

308. Whitcomb DC, Taylor IL, Vigna SR: Characterization of saturable binding sites for circulating pancreatic polypeptide in rat brain. Am. J. Physiol. 259, G687-G691 (1990)

309. White CM, Poxon V, Alexander-Williams J: Effects of nutrient liquids on human gastroduodenal motor activity. Gut 24, 1109-1116 (1983)

310. Wierup N, Björkqvist M, Westrom B, Pierzynowski S, Sundler F, Sjölund K: Ghrelin and motilin are cosecreted from a prominent endocrine cell population in the small intestine. J. Clin. Endocrinol. Metab. 92, 3573-3581 (2007)

311. Wilbur BG, Kelly KA: Gastrin pentapeptide decreases canine gastric transmural pressure. Gastroenterology 67 , 1139-1142 (1974)

312. Wilmer A, Tack J, Coremans G, Janssens J, Peeters T, Vantrappen G: 5-hydroxytryptamine-3 receptors are involved in the initiation of gastric phase-3 motor activity in humans. Gastroenterology 105, 773-780 (1993)

313. Wingate DL: Backwards and forwards with the migrating complex. Dig. Dis. Sci. 26, 641-666 (1981)

314. Wingate DL: Complex clocks. Dig. Dis. Sci. 28, 1133-1140 (1983)

315. Wingate DL, Pearce EA, Hutton M, Dand A, Thompson HH, Wünsch E: Quantitative comparison of the effects of cholecystokinin, secretin, and pentagastrin on gastrointestinal myoelectric activity in the conscious dog. Gut 19, 593-601 (1978)

316. Wingate DL, Ruppin H, Green WER, Thompson HH, Domschke W, Wünsch E, Demling L, Ritchie HD: Motilin-induced electrical activity in the canine alimentary tract. Scand. J. Gastroenterol. 11(Suppl. 39), 111-118 (1976)

317. Wingate DL, Ruppin H, Thompson HH, Green WER, Domschke W, Wünsch E, Demling L, Ritchie HD: 13-Norleucine motilin versus pentagastrin: contrasting and competitive effects on gastrointestinal myoelectric activity in conscious dogs. Acta Hepato-Gastroenterol. 22, 409-410 (1975)

318. Woodtli W, Owyang C: Duodenal pH governs interdigestive motility in humans. Am. J. Physiol. 268, G146-G152 (1995) 
319. Xu L, Depoortere I, Tomasetto C, Zandecki M, Tang M, Timmermans JP, Peeters TL: Evidence for the presence of motilin, ghrelin and the motilin and ghrelin receptor in neurons of the myenteric plexus. Regul. Pept. 124, 119-125 (2005)

320. Yamada T, Chiba T (1989): Somatostatin. In: Handbook of Physiology. The Gastrointestinal System, ed Schultz SG, American Physiological Society, Bethesda, MD, pp. 431-453

321. Yamada T, Mizumoto A, Satoh M, Haga N, Itoh Z: Muscarinic control of phase III contractions and motilin release in dogs. Peptides 18, 673-680 (1997)

322. Yamagishi T, Debas HT: Cholecystokinin inhibits gastric emptying by acting on both proximal stomach and pylorus. Am. J. Physiol. 234, E375-E378 (1978)

323. Yoshiya K, Yamamura T, Ishikawa Y, Utsunomiya J, Mori K, Seino Y, Imura H, Yanaihara N: The failure of truncal vagotomy to affect motilin release in dogs. J. Surg. Res. 38, 263-266 (1985)

324. Zabbin MA, Wamsley JK, Innis RB, Kuhar MJ: Cholecystokinin receptors: presence and axonal flow in the rat vagus nerve. Life Sci. 29, 697-705 (1981)

325. Zenilman ME: Origin and control of gastrointestinal motility. Surg. Clin. North Am. 73, 1081-1099 (1993)

326. Zenilman ME, Parodi JE, Becker JM: Preservation and propagation of cyclic myoelectric activity after feeding in rat small intestine. Am. J. Physiol. 263, G248-G253 (1992) 